
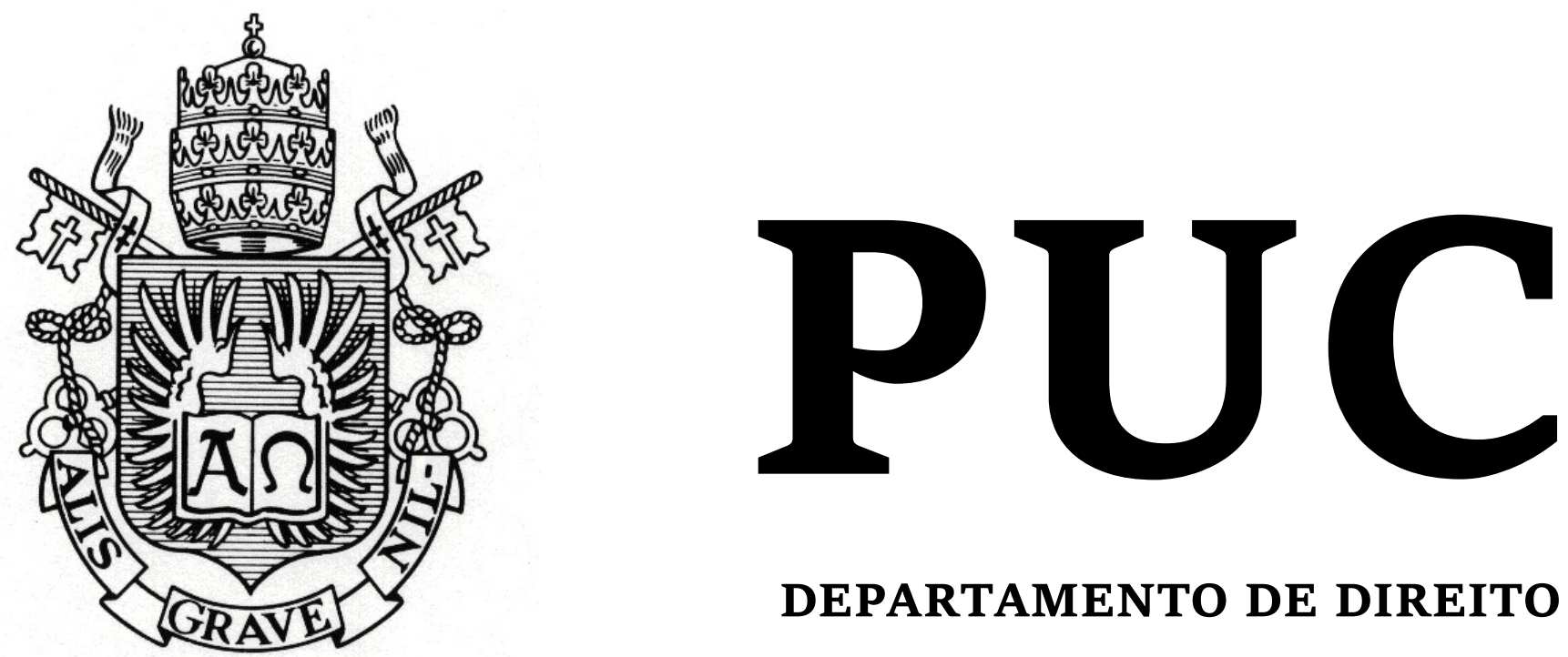

DEPARTAMENTO DE DIREITO

O uso de standards na análise de transações entre o acionista controlador e a companhia

por

Rafael Vieira de Andrade de Sá

ORIENTADOR: Pablo W. Renteria

2017.1

PONTIFÍCIA UNIVERSIDADE CATÓLICA DO RIO DE JANEIRO

RUA MARQUÊS DE SÃO VICENTE, 225 - CEP 22453-900

RIO DE JANEIRO - BRASIL 


\title{
O uso de standards na análise de transações entre o acionista controlador e a companhia
}

\author{
por \\ Rafael Vieira de Andrade de Sá
}

\begin{abstract}
Monografia apresentada ao Departamento de Direito da Pontifícia Universidade Católica do Rio de Janeiro (PUC-Rio) para a obtenção do Título de Bacharel em Direito.
\end{abstract}

Orientador: Pablo W. Renteria 
"In business law, the lawyer who fails to understand the economics of a problem usually fails to find a satisfactory solution to the problem".

(William T. Allen, Reinier Kraakman e Guhan Subramanian) 


\section{AGRADECIMENTOS}

Diz-se, por aí, que a felicidade somente é real quando compartilhada.

Para a minha sorte, ao longo de toda a minha vida, sempre tive presente pessoas incríveis que comigo compartilharam as mais diversas realizações. Este, certamente, é um desses momentos - e, pela conjugação de muitos fatores, arrisco a dizer que talvez seja o mais importante deles, ao menos até agora. Afinal, ao ultimar, neste semestre, os mais de cinco anos de faculdade de Direito na Pontifícia Universidade Católica do Rio de Janeiro e de trabalho na Comissão de Valores Mobiliários, concluo não apenas um, mas dois inesquecíveis ciclos.

Nada mais justo, assim, que dedicar algumas palavras àqueles que vêm me acompanhando e apoiando nessa jornada.

Começo, como não poderia deixar de ser, agradecendo àqueles que são a minha estrutura, que tudo me ensinaram e a quem tudo devo: meu pai, João Ricardo de Andrade de Sá, e minha mãe, Andrea Vieira Milhoranse de Sá. É difícil, poderia até mesmo dizer impossível, transpor em palavras minha gratidão a vocês, que por meio de inúmeros sacrifícios possibilitaram-me chegar até aqui. Apesar de todos os percalços, apoiados uns nos outros, vencemos - juntos - mais um desafio. Sem vocês, não é exagerado dizer, nada disso teria sido possível. Obrigado por tudo.

Às minhas irmãs, Adriana e Sandy Milhoranse, agradeço por terem estado ao meu lado em todos os momentos, bons e ruins. Ambas, cada uma a sua maneira, inspiram-me a ser uma pessoa melhor. A dedicação, foco e profissionalismo de uma, a alegria, carisma e leveza de outra, são características que admiro e busco incorporar em minha vida. A propósito: enfim, formei!

Às minhas avós, Otília de Sá e Sônia Vieira, agradeço pelo amor e chamego que só as avós, mães duas vezes que são, podem oferecer. Aos meus tios e primos, obrigado por todo o apoio e suporte que me deram para 
enfrentar todo esse processo.

Aos meus amigos de CTUR e agregados, em especial Gabriel Nunes, Pedro Moura, Cristiane Ligeiro, Marianna Nunnis, Rodrigo Moura, Beatriz Soares, Victor Geschwind e Marvin Fellipe, gostaria de mais uma vez agradecer por sua amizade. Ainda que nossa convivência não tenha sido tão frequente nos últimos anos, porque, enfim, a vida segue seu rumo, sei que sempre levo um pedaço de cada um de vocês e que a vitória de cada um traz felicidade aos outros.

Aos amigos de PUC-Rio, certamente a melhor parte dessa experiência foi ter conhecido vocês. As conversas, festas e risadas são momentos que levarei para todo o sempre. A graduação não é algo fácil, mas vocês me ajudaram a passar por todo esse processo e, por isso, sei que essa vitória é de todos nós, coletivamente. Ana Leão, Caio Agib, Carolina Maisonnette, Carolina Fontes, Catharina Monnerat, Jéssica Perez, Loane Brollo, Luiz Gustavo, Matheus Coutinho, Mateus Camelier, Márcio Rabello, Millena Aranha, Rebeca Arbex, Ricardo Abreu, Vinícius Vilhena e Vitória Lopes, muito obrigado por tudo.

Mas a faculdade, é claro, não se resume aos amigos. Aqui, em nome de todos os professores que, com absoluta dedicação, buscaram transmitir um pouco de seu conhecimento para nós, alunos, deixo um grande agradecimento à professora Aline Terra, cujo amor por seu trabalho, além da ética, postura e conhecimento inigualáveis, indica-me claramente o profissional que almejo ser.

Se é difícil encerrar o ciclo da faculdade, fazer isso finalizando outro tão importante quanto deixa o processo ainda mais tormentoso. Após mais de seis anos, saio da CVM, onde comecei meu primeiro estágio ainda com dezoito anos e no início da faculdade. Trabalhar na CVM certamente foi das experiências mais enriquecedoras que já tive, não apenas pelos conhecimentos adquiridos, mas também pelas incríveis pessoas que conheci ao longo do caminho. 
Aos amigos de SEP, notadamente Davi Batista, Dov Rawet, Eduardo Mendes, Fernando Vieira, Jorge Andrade, Vicente Camillo, Leonardo Faccini, Sandro Chagas e Thiago Salinas, agradeço pelo acolhimento, paciência e amizade durante os mais de cinco anos que trabalhamos juntos, bem como pela atenção a todas as minhas (infindáveis) perguntas. Em especial, agradeço à Juliana Bento, pela oportunidade e carinho ao longo desses últimos anos.

Aos queridos companheiros de Colegiado, especialmente Ana Nezi, Antonio Emydgio, Ary Costa Neto, Camila Pantera, Diego Paixão, Edson Nakamura, Juliana Souza, Marcelo Ribeiro, Maria Antonia Barretto, Pedro Brigagão e Roberta Sultani, deixo aqui meu mais absoluto agradecimento por esse relativamente curto, porém memorável, período em que trabalhamos juntos. Certamente será difícil encontrar, ao longo de minha experiência profissional, outro lugar que concentre pessoas tão inteligentes e dedicadas quanto as que conheci neste ano. Mas, é claro, sentirei saudades não apenas das relevantes discussões sobre direito societário e mercado de capitais, mas também - e principalmente - da diária companhia de todos.

Agradeço, também, ao Gustavo Borba, pela incrível e única oportunidade de me permitir ser seu assessor no Colegiado, bem como pela confiança em mim depositada nesse ano em que trabalhos juntos.

Ao Pablo Renteria, agradeço por ter aceitado me orientar nesta empreitada final da faculdade e pelas valiosas contribuições para o desenvolvimento deste trabalho.

Ao finalizar esse texto, seguramente dos mais difíceis que já escrevi, percebo que o crédito pelas realizações que obtive pertence, sobretudo, aos que, com amizade, amor, carinho e consideração, agraciaram-me com sua presença em minha vida. E, se é verdade que nada é pesado para aqueles que têm asas, como forjado no brasão da PUC-Rio, só tenho a agradecer, a todos vocês, por serem as minhas. 


\section{RESUMO}

SÁ, Rafael Vieira de Andrade de. $O$ uso de standards na análise de transações entre o acionista controlador e a companhia. 87p. Monografia (Graduação em Direito) - Pontifícia Universidade Católica do Rio de Janeiro: Rio de Janeiro, 2017.

O presente trabalho tem por objetivo examinar o modo de aplicação da estratégia regulatória baseada em standards na análise de operações de reestruturação societária que envolvem o acionista controlador e a companhia. Para isso, com o fim de melhor entender como funcionam tais estratégias no mencionado contexto, analisar-se-á como ocorre a sua aplicação nos Estados Unidos, em especial pelas cortes de Delaware. Além disso, será realizada uma análise crítica da tentativa de internalização do modelo norte-americano de aplicação de standards, que foi promovida pela Comissão de Valores Mobiliários com a edição do Parecer de Orientação $\mathrm{CVM} \mathrm{n}^{\circ} 35$, de 2008.

Palavras Chave: Direito Societário - Mercado de Capitais - Sociedade Anônima - Conflitos de Agência - Acionista Controlador - Estratégias Regulatórias - Standards - Reestruturação Societária - Comissão de Valores Mobiliários. 


\section{SUMÁRIO}

Introdução ..................................................................................................................... 8

Capítulo I. Conflitos de agência nas companhias........................................... 13

I.1. A natureza econômica da empresa .............................................. 13

I.2. Teoria da agência: problemas e custos......................................... 17

I.3. Conflitos de agência nas companhias ........................................... 19

I.4. Estratégias de controle dos custos de agência................................23

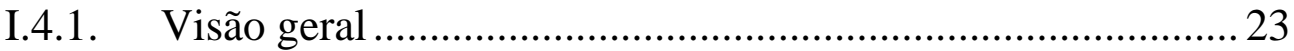

I.4.2. Estratégias regulatórias de associação .....................................24

I.4.3. Estratégias de governança ...................................................25

I.4.4. Estratégias regulatórias de controle ………….......................2 28

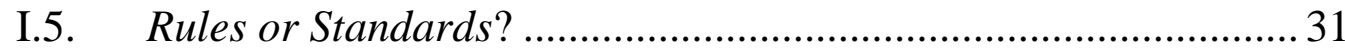

Capítulo II. O modelo norte-americano .............................................................. 35

II.1. Definição de acionista controlador...................................................... 35

II.2. Standard of conduct: o controlador como fiduciário .......................36

II.3. Standard of review: o entire fairness test .......................................4 46

II.3.1. As facetas do entire fairness test ............................................ 46

II.3.1.1. Preço justo (fair price) ...................................................... 47

II.3.1.2. Processo justo de negociação (fair dealing) .................... 48

II.3.1.3. A correlação entre o fair dealing e o fair price ............... 50

II.4. A aplicação do entire fairness test ..............................................51

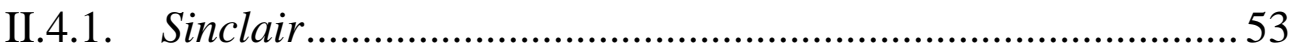

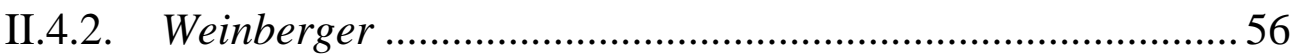

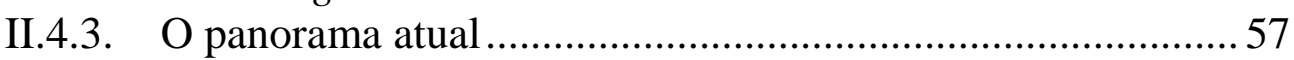

II.5. A proteção dos safe harbor statutes ...............................................59

II.6. Análise crítica da evolução jurisprudencial norte-americana .......65

Capítulo III. Uma tentativa de internalização do modelo norte-

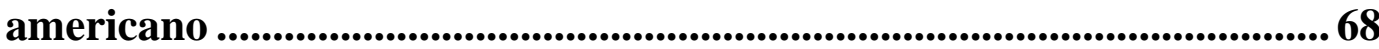

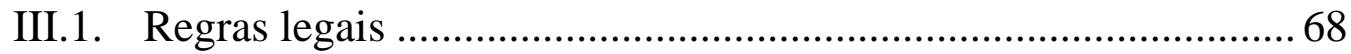

III.2. Parecer de Orientação CVM nº 34, de 2006 ................................ 72

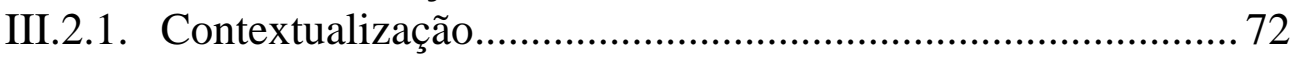

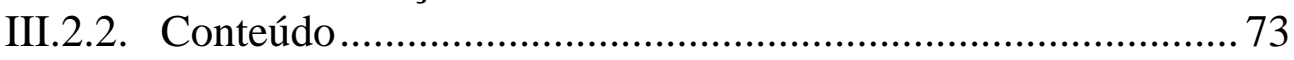

III.2.3. A estratégia adotada pela CVM..........................................74

III.3. Parecer de Orientação CVM no 35, de 2008 ................................. 76

III.3.1. Contextualização................................................................ 76

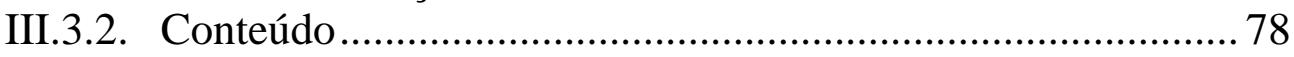

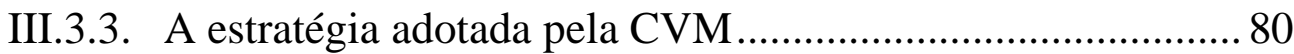

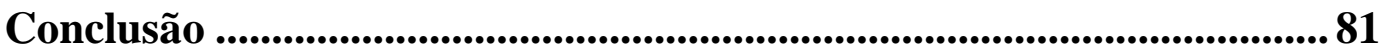

Bibliografia................................................................................................................... 84 


\section{INTRODUÇÃO}

Pode-se dizer que o mercado de capitais, em certa medida, consiste numa alternativa quase mágica de financiamento empresarial ${ }^{1}$. Afinal, tratase de um sistema em que milhares de pessoas fornecem seus recursos para serem geridos por terceiros, que às vezes sequer conhecem, em troca de direitos cujos valores os investidores estipulam principalmente com base em informações públicas, sendo que, em muitos casos, os investidores não possuem qualquer garantia de retorno de seu investimento.

Apesar desse cenário no mínimo desafiador, é certo que, em âmbito mundial, o mercado de capitais se firmou como o meio mais utilizado para a captação do capital necessário para o financiamento de atividades empresariais. E, nesse contexto, a sociedade anônima constitui a principal instituição jurídica utilizada em diversas jurisdições para a obtenção de recursos no mercado de capitais. Sem o tipo societário anônimo, sustentam LAMY FILHO \& BULHÕES PEDREIRA, não teria sido possível a mobilização de capital necessária para alcançar o estágio atual de desenvolvimento das mais variadas atividades econômicas ${ }^{2}$.

O sucesso da sociedade anônima, de acordo com ALLEN et al, advém, dentre outros fatores, do fato de que as leis societárias que regulam as relações entre os principais grupos que orbitam seu universo, notadamente os fornecedores de capital próprio (acionistas) e os gestores da empresa (administradores), inexistindo, assim, a necessidade de que esses agentes econômicos definam por meio de contratos individuais seus direitos e deveres, o que seria altamente custoso ${ }^{3}$. Alertam os autores, contudo, ser inerente a esse tipo societário a existência de conflitos entre esses grupos,

\footnotetext{
${ }^{1}$ BLACK, Bernard S. Legal and Institutional Preconditions for Strong Securities Markets. UCLA Law Review, v. 48, 2001, p. 782.

2 LAMY FILHO, Alfredo; BULHÕES PEDREIRA, José Luiz. Introdução. In: Direito das Companhias. Coord.: LAMY FILHO, Alfredo; PEDREIRA, José Luiz Bulhões. Rio de Janeiro: Forense, 2009, p. 2.

${ }^{3}$ ALLEN, Willian T. et al. Commentaries and Cases on The Law of Business Organization. Nova York: Aspen Publishers, 2009, p. 13.
} 
os quais precisam ser equacionados para a garantia do pleno e sustentável desenvolvimento da companhia e do próprio mercado de capitais ${ }^{4}$.

Nesse sentido, além do estabelecimento das regras básicas relativas às sociedades anônimas, que tangenciam notadamente cinco pontos fundamentais (personalidade jurídica com prazo indeterminado, limitação de responsabilidade dos acionistas, livre transferibilidade das ações, administração centralizada e regras relativas à propriedade acionária), as leis societárias executam a primordial função de criar mecanismos com o fim de reduzir os conflitos de interesses existentes entre os diversos stakeholders das companhias ${ }^{5}$.

Um desses conflitos, objeto de estudo do presente trabalho, ocorre entre os acionistas controladores e não-controladores. Em razão da maioria de votos que detém, o controlador dirige as atividades sociais e orienta o funcionamento dos órgãos da companhia, com a certeza de que sua visão de negócio prevalecerá nas assembleias de acionistas. Surge inevitavelmente, com a existência de um acionista controlador, o potencial risco de que este se utilize de seu poder de controle para fins egoísticos, ou seja, com o objetivo de favorecimento próprio ou de outras sociedades, em prejuízo dos acionistas minoritários da companhia. O referido fenômeno, também conhecido como "tunneling", pode ser assim explicado:

Tunneling can be done in many ways, and some often seen forms of tunneling include transfer-pricing-contracts advantageous to the controlling shareholder, loan guarantees, expropriation of corporate opportunities, and so on. Through tunneling, company resources are transferred to the controlling shareholders and the minorities are excluded from sharing those resources. Economists call these benefits received by the controlling shareholders 'private benefits of control' ('PBC'). If the level of PBC extraction is too high, investors will be less willing to invest in a controlled company. This, in turn, will lead to the lowering of company value, rise of capital cost and, in the end, underdevelopment of the capital market.

Tunneling is one of the major forms of value-reducing opportunism among different corporate constituencies, and is the most prominent challenge faced by

\footnotetext{
${ }^{4}$ Ibid., p. 13.

5 KRAAKMAN, Reinier et al. The Anatomy of Corporate Law: A Comparative and Functional Approach. $2^{\text {a }}$ edição. Oxford: Oxford University Press, 2009, p. 36.
} 
corporate law regarding controlled companies ${ }^{6}$.

Existem, essencialmente, três formas pelas quais o acionista controlador consegue extrair benefícios privados decorrentes do poder de controle por ele detido ${ }^{7}$. A primeira delas consiste na realização de contratos com a companhia que resultem em vantagens econômicas desproporcionais comparativamente ao valor de mercado dos bens negociados ou dos serviços prestados pelo/ao controlador. A segunda forma sucede através da alienação das ações detidas pelo controlador, com a consequente transferência do poder de controle por elas conferido, a um preço superior ao valor de mercado daqueles valores mobiliários. A última, ao seu turno, ocorre quando os controladores de algum modo conseguem diminuir ou eliminar a participação dos acionistas minoritários do quadro acionário da companhia, o que pode ser feito por meio de uma oferta pública de aquisição de ações ou através de uma reestruturação societária ${ }^{8}$.

Para cada um desses cenários, as leis societárias empregam estratégias com o fim de atenuar o conflito entre os acionistas controladores e não-controladores, a fim de mitigar a possibilidade de expropriação de valor por parte daqueles. Essa necessidade de proteção do investidor decorre do fato de que o desenvolvimento do mercado de capitais sofre substancial influência do grau de confiança presente entre seus participantes. Afinal, quando os investidores receiam o desvio ou o mau uso de seus recursos, passam a descontar esse risco do preço dos valores mobiliários por eles adquiridos, afetando negativamente o mercado como um todo. Por essa perspectiva, proteger o investidor significa proteger o

\footnotetext{
${ }^{6}$ FAN, Chunyan. Bringing Controlling Shareholders to Court: Standard-Based Strategies and Controlling Shareholder Opportunism. A Haia: Eleven International Publishing, 2013, pp. 2-3.

${ }^{7}$ GILSON, Ronald J.; GORDON, Jeffrey N. Controlling controlling shareholders. Disponível em <http://papers.ssrn.com/abstract=417181>. Acesso em 27 de abril de 2017.

8 Como explicam GILSON \& GORDON, em uma companhia aberta com controlador definido, a cotação das ações de sua emissão reflete o valor de uma ação pertencente ao acionista não controlador, posto que o preço da ação no mercado é descontado do montante dos benefícios privados capitalizados pelo controlador. $\mathrm{O}$ controlador, ao expulsar os acionistas minoritários da companhia (freeze-out) pelo preço de mercado da ação, consegue capturar o valor dos seus futuros benefícios privados. Ob. Cit, p. 5 .
} 
próprio desenvolvimento do mercado.

O foco deste trabalho são as estratégias utilizadas com o fim de controlar o potencial conflito entre acionistas controladores e nãocontroladores no contexto de reestruturações societárias que envolvam companhias controladas e suas controladoras, operações que, no Brasil, são reguladas notadamente pelo art. 264 da Lei $n^{\circ}$ 6.404, de 1976. Nessas operações, como exposto na própria Exposição de Motivos da lei societária brasileira, inexistem "duas maiorias acionárias distintas, que deliberem separadamente sobre a operação, defendendo os interesses de cada companhia". Há, assim, assim, a necessidade de que tais operações sejam cercadas de normas especiais de proteção aos acionistas minoritários, dado o potencial risco de que os controladores se utilizem se sua posição para forçar uma operação com condições não comutativas.

De acordo com KRAAKMAN et al, ao redor do mundo, a principal estratégia para a análise dessas transações consiste no uso de standards, ou seja, na atribuição de um padrão de comportamento ao acionista controlador, deixando-se para um momento posterior a aferição da correção de sua conduta ${ }^{10}$. Nesse sentido, com o fim de melhor entender como funcionam as estratégias baseadas em standards no contexto anteriormente referido, analisar-se-á como ocorre a sua aplicação nos Estados Unidos, em especial pelas cortes de Delaware, altamente especializadas em direito societário e onde essa estratégia encontra-se presente há décadas, havendo, assim, vasta base jurisprudencial para um exame aprofundado da matéria.

O estudo do modelo norte-americano se faz necessário também para possibilitar uma análise crítica do tratamento dado à questão pela Comissão de Valores Mobiliários, órgão regulador do mercado de capitais brasileiro, que tentou, na prática, internalizar o modelo norte-americano no direito

\footnotetext{
${ }^{9}$ Exposição de Motivos no 196 , de 24 de junho de 1976, do Ministério da Fazenda.

${ }^{10}$ KRAAKMAN, Reinier et al. Ob. Cit., p. 75.
} 
pátrio, por meio da edição do Parecer de Orientação CVM n ${ }^{\circ} 35$, de $2008^{11}$.

Busca-se, ao fim do presente trabalho, analisar criticamente a existência ou não de efetiva possibilidade de incorporação do modelo norteamericano de aplicação de standards no direito pátrio pela CVM. Para tanto, dividiu-se esta monografia em três capítulos. $\mathrm{O}$ primeiro dedica-se a explorar os conflitos existentes entre os diversos grupos que orbitam o universo das companhias e as estratégias que podem ser aplicadas nesse contexto. No segundo capítulo, a partir da análise de doutrina e jurisprudência, estuda-se o modo de aplicação dos standards nos Estados Unidos. No terceiro e último capítulo, por sua vez, examina-se o tratamento dado à matéria pela CVM e a tentativa de incorporação da prática norteamericana no direito brasileiro.

\footnotetext{
${ }^{11}$ Nesse sentido, referindo-se à audiência pública que culminou na edição do referido parecer, afirmou CANTIDIANO: "Agora a CVM submete a consulta pública a edição de novo Parecer de Orientação em que importa de legislação estrangeira procedimentos e regras que, à toda evidência, não vigoram em nosso país e, mais que isso, que não podem ser impostos por intermédio de Parecer de Orientação". CANTIDIANO, Luiz Leonardo. Análise Crítica do Parecer de Orientação CVM 34. Revista de Direito Bancário e do Mercado de Capitais (RT Online), Vol. 41, julho de 2008, p. 2.
} 


\section{CAPÍTULO I. CONFLITOS DE AGÊNCIA NAS COMPANHIAS}

\section{I.1. A natureza econômica da empresa}

A combinação entre a divisão de seu capital social em ações e a limitação de responsabilidade dos sócios ao preço de emissão das ações subscritas ou adquiridas, características fundamentais das sociedades anônimas ${ }^{12}$, fez com que esse tipo societário se tornasse a principal instituição jurídica a modelar a economia mundial desde o seu aparecimento $^{13}$.

É inusitado notar, nesse contexto, que SMITH, economista que revolucionou o pensamento econômico moderno ${ }^{14}$, não acreditava no domínio do sistema capitalista pelas sociedades anônimas. Ao contrário, em seu estudo sobre a natureza e as causas da riqueza das nações, publicado pela primeira vez em 1776, o autor dedicou diversas páginas para demonstrar que, em regra, as companhias seriam economicamente ineficientes e ainda dependeriam, para o seu eventual êxito, da concessão de privilégios de exclusividade ${ }^{15-16}$.

\footnotetext{
${ }^{12}$ Não por outro motivo, essas características são mencionadas logo no art. $1^{\circ}$ da Lei $n^{\circ} 6.404$, de 1976, a lei societária brasileira.

${ }^{13}$ Entende-se ter sido a Companhia das Índias Ocidentais, fundada no Século XVII, a primeira sociedade por ações. Nesse sentido: LAMY FILHO, Alfredo; BULHÕES PEDREIRA, José Luiz. Introdução. Ob. Cit, p. 3.

${ }^{14}$ Como se sabe, a doutrina econômica de Adam Smith foi historicamente resumida na defesa de ausência de intervenção estatal no mercado, pois este seria guiado por uma "mão invisível". A expressão, no entanto, apenas foi utilizada em uma ocasião pelo autor em sua obra mais famosa, na seguinte passagem, digna de nota: "Ao preferir fomentar a atividade do país e não de outros países ele [o indivíduo] tem em vista apenas sua própria segurança; e orientando sua atividade de tal maneira que sua produção possa ser de maior valor, visa apenas a seu próprio ganho e, neste, como em muitos outros casos, é levado como que por mão invisível a promover um objetivo que não fazia parte de suas intenções. Aliás, nem sempre é pior para a sociedade que esse objetivo não faça parte das intenções do indivíduo. Ao perseguir seus próprios interesses, o indivíduo muitas vezes promove o interesse da sociedade muito mais eficazmente do que quando tenciona realmente promovê-lo. Nunca ouvi dizer que tenham realizado grandes coisas para o país aqueles que simulam exercer o comércio visando ao bem público. Efetivamente, é um artifício não muito comum entre os comerciantes, e não são necessárias muitas palavras para dissuadi-los disso". SMITH, Adam. A Riqueza das Nações: Investigação Sobre sua Natureza e suas Causas. Vol II. Trad.: Luiz João Baraúna. São Paulo: Nova Cultural, 1996, p. 438.

${ }^{15}$ Ibid., p. 227.

${ }^{16}$ Essa situação apenas seria excepcionada, no entendimento de SMITH, pelo exercício de atividades empresariais pelas sociedades anônimas nos setores bancário, de comércio de seguros contra incêndios e riscos marítimos, de construção e manutenção de passagem ou canal navegável,
} 
Com efeito, analisando casos de insucesso de diversas companhias que atuaram notadamente nos Século XVII e XVIII, dentre as quais a Companhia das Índias Orientais, o economista vaticinou que as sociedades anônimas somente serviriam para o exercício de atividades produtivas cujas operações poderiam "ser reduzidas ao que se chama rotina, ou a tal uniformidade de método que comporte pouca ou nenhuma variação" 17 .

Em suma, a conclusão contundente de SMITH decorreu de sua análise sobre um dilema que, até os dias atuais, inquieta aqueles que, por meio do mercado de capitais, investem seu patrimônio em companhias: a possível atuação negligente dos administradores na gestão da sociedade ou - pior - a atuação desses profissionais voltada para o atendimento de seus próprios interesses ou de terceiros, em detrimento dos legítimos interesses da sociedade anônima (e, por consequência, de seus acionistas).

$\mathrm{O}$ entendimento do economista a respeito deste tema encontra-se perfeitamente ilustrado no seguinte trecho de sua mais relevante obra:

Entretanto, sendo que os diretores de tais companhias administram mais do dinheiro de outros do que o próprio, não é de esperar que dele cuidem com a mesma irrequieta vigilância com a qual os sócios de uma associação privada frequientemente cuidam do seu. Como os administradores de um homem rico, eles têm propensão a considerar que não seria honroso para o patrão atender a pequenos detalhes, e com muita facilidade dispensam esses pequenos cuidados. Por conseguinte, prevalecem sempre e necessariamente a negligência e o esbanjamento, em grau maior ou menor, na administração dos negócios de uma companhia. É por isso que as companhias de capital acionário para o comércio exterior raramente têm sido capazes de sustentar a concorrência contra aventureiros privados. Conseqüentemente, poucos êxitos têm obtido sem qualquer privilégio de exclusividade e, muitas vezes, nem sequer com isto têm logrado sucesso. Sem um privilégio de exclusividade, geralmente têm administrado mal o comércio. Com tal privilégio, além de administrar mal, têm limitado o comércio ${ }^{18}$.

Indo além, SMITH observou que os acionistas de grandes companhias enfrentam dificuldades no monitoramento e controle da atuação dos administradores e, às vezes, dado o elevado custo necessário para o exercício dessas atividades (comparativamente ao patrimônio

e de abastecimento de água de grandes cidades. Ibid., p. 225.

${ }^{17}$ Ibid., p. 225.

${ }^{18}$ Ibid., p. 214. 
individual investido), sequer possuem interesse em fazê-lo ${ }^{19}$.

A questão levantada por SMITH a respeito dos incentivos que orientam os administradores foi posteriormente examinada por COASE, que buscou descobrir o motivo pelo qual a figura da empresa surge em uma economia especializada. Em 1937, COASE publicou seminal artigo contestando a ideia, largamente aceita, de que a eficiência do mercado, a busca pela maximização de utilidade e a racionalidade econômica aproximam de forma natural os vendedores e os compradores dispostos a estabelecer o preço da transação em um patamar de equilíbrio aceitável para $\operatorname{ambos}^{20}$. Essa teoria econômica clássica pode ser apresentada nos seguintes dizeres de SALTER:

The normal economic system works itself. For its current operation it is under no central control, it needs no central survey. Over the whole range of human activity and human need, supply is adjusted to demand, and production to consumption, by a process that is automatic, elastic and responsive ${ }^{21}$.

Ao reverso do sustentado pela teoria econômica clássica, a doutrina de COASE prega, em síntese, que os empresários incorrem em custos, denominados "custos de transação", durante a procura no mercado pelos melhores preços para os seus negócios, de modo que essas despesas, em determinadas situações, podem potencialmente superar os benefícios econômicos de uma negociação livre no mercado ${ }^{22}$. Nesses casos, segundo o mencionado economista, torna-se mais eficiente, do ponto de vista econômico, a criação de uma organização hierarquizada e coordenada para a realização de determinadas tarefas necessárias à consecução da atividade

\footnotetext{
${ }^{19}$ Diz SMITH: "Entretanto, parece impossível que através de quaisquer alterações se possa tornar assembléias aptas, sob qualquer aspecto, a governar um grande império, ou até participar do governo do mesmo, pois a maior parte de seus membros necessariamente tem muito pouco interesse na prosperidade desse império para dispensar atenção àquilo que pode promovê-la". Ibid., p. 222.

${ }^{20}$ COASE, Ronald. The Nature of the Firm. Economica, New Series, Vol. 4, n. 16, Nov., 1937, p. 387.

${ }^{21}$ SALTER, Arthur apud COASE, Ronald, Ob. Cit., p. 386.

${ }^{22}$ Nas palavras de COASE: "The main reason why it is profitable to establish a firm would seem to be that there is a cost of using the price mechanism". Ob. Cit., p. 390.
} 
produtiva: a empresa ${ }^{23}$.

Em outras palavras, de acordo com COASE, a figura da empresa surge quando os custos de transação são muito altos, em decorrência, por exemplo, da necessidade de profunda negociação e de substancial investimento para a busca dos melhores preços no mercado, sendo assim mais eficiente, sob o prisma econômico, em comparação à realização de complexas e reiteradas operações individualizadas de compra e venda no mercado, a concentração de diversas transações em uma estrutura unificada.

Para o autor, portanto, a supressão do mecanismo de preço que governa o mercado consiste na fronteira que demarca o seu fim e o consequente início da empresa ${ }^{24}$, porque nessa a alocação de fatores de produção de um lado a outro não decorre da aplicação da lei de oferta e demanda, mas sim por uma orientação superior preordenada. Essa diferença é assim explicada por COASE:

For instance, in economic theory we find that the allocation of factors of production between different uses is determined by the price mechanism. The price of factor $\mathrm{A}$ becomes higher in $\mathrm{X}$ than in $\mathrm{Y}$. As a result, A moves from $\mathrm{Y}$ to $\mathrm{X}$ until the difference between the prices in $\mathrm{X}$ and $\mathrm{Y}$, except in so far as it compensates for other differential advantages, disappear. Yet in the real world, we find that there are many areas where this does not apply. If a workman moves from department $\mathrm{Y}$ to department $\mathrm{X}$, he does not go because of a change in relative prices, but because he is ordered to do $\mathrm{so}^{25}$.

$\mathrm{Na}$ esteira das lições de COASE diversos economistas debruçaramse sobre o tema por ele inovadoramente delineado, buscando explicar como, porque e até aonde a empresa, em seu aspecto econômico, pode ser entendida como um conjunto de transações que tem por precípuo objetivo possibilitar a redução dos custos de transação existentes no mercado; dessas indagações surgiram, por exemplo, as terias que enxergam a empresa como

\footnotetext{
${ }^{23}$ O termo utilizado por COASE é a expressão inglesa "firm". Entretanto, no presente trabalho, optou-se por utilizar, para facilitação de compreensão, o termo "empresa". É necessário frisar, no entanto, que a definição da "empresa" aqui mencionada foge à sua definição jurídica, representando, em verdade, um fenômeno econômico.

${ }^{24}$ COASE, Ronald. Ob. Cit., p. 389.

${ }^{25}$ Ibid., p. 387.
} 
um "nexus of contracts"26.

Mas, fundamentando-se na mesma fonte, e ainda com base nas vicissitudes citadas por SMITH, alguns estudiosos, dentre os quais se destacam JENSEN \& MECKLING, analisaram a questão sob o foco do que ficou conhecido na doutrina econômica como "teoria da agência", 27 , prisma que nos interessa para fins deste trabalho.

\section{I.2. Teoria da agência: problemas e custos}

Conforme a definição de JENSEN \& MECKLING, existe uma relação de agência, em sentido econômico, quando uma pessoa ou um conjunto de pessoas (o "principal") contrata outra (o "agent") para prestar em seu nome algum serviço, implicando em algum tipo de delegação de poder de decisão do principal para o agent $^{28}$. Partindo do pressuposto econômico de que todas as pessoas perseguem a maximização de sua própria utilidade, os autores sustentam haver fundados motivos para acreditar que o agent nem sempre atuará no melhor interesse do principal.

Complica-se essa situação com a constatação de que, em regra, o agent possui mais e melhores informações a respeito de fatos relevantes

\footnotetext{
${ }^{26}$ Sobre tais teorias, v. MILLON, David. Theories of the Corporation. Duke Law Journal, V. 1990, N. 2, Frontiers of Legal Thought I, 1990, pp. 201-262.

${ }^{27}$ Antes de analisar a referida teoria, é necessário melhor explicar a literalidade da expressão em vernáculo, posto que a teoria em questão é originalmente conhecida, na língua inglesa, como "agency theory". Como se poderá verificar no presente trabalho, a tradução "teoria da agência" aparentemente padece de equívoco, posto que, em princípio, melhor se coadunaria à expressão "teoria de mandato".

Com efeito, o instituto jurídico anglo-saxão agency, utilizado pelos economistas para formular a referida teoria, melhor corresponderia ao nosso contrato de mandato, disciplinado nos arts. 653 a 666 do Código Civil, e não ao contrato de agência de que trata o Capítulo XII do mesmo diploma legal, como se pode extrair da própria definição contida no \$1.01 do Restatement of the Law of Agency (Third): "Agency is the fiduciary relationship that arises when one person (a "principal") manifests assent to another person (an "agent") that the agent shall act on the principal's behalf and subject to the principal's control, and the agent manifests assent or otherwise consents so to act". Ocorre, porém, que se encontra consolidado na doutrina econômica nacional, em especial nos trabalhos acadêmicos, o uso da expressão "teoria da agência" como tradução do inglês "agency theory". Desse modo, para a manutenção do paralelismo do presente trabalho com as demais produções nacionais que tangem o assunto, optou-se por aqui utilizar "teoria da agência", bem como os seus respectivos desdobramentos.

28 JENSEN, Michael C.; MECKLING, William H. Theory of the Firm: Managerial Behavior, Agency Costs and Ownership Structure. Disponível em < http://papers.ssrn.com/abstract=94043>. Acesso em 19 de março de 2017.
} 
para os negócios do principal, o qual, por sua vez, tem a sua disposição somente meios limitados para aferir a correção da atuação do agent. Este, por consequência, tem incentivos para atuar de forma egoística ${ }^{29}$, seja prestando serviços de má qualidade, seja direcionando para si aquilo que deveria ser auferido pelo principal, o que se denomina de problemas ou conflitos de agência.

A questão central que surge nesse contexto concerne à necessidade de criação de incentivos econômicos suficientes para motivar o agent a atuar em conformidade com os interesses do principal $^{30}$. Nesse sentido, a fim de evitar a possível divergência de interesses, o principal pode aplicar incentivos adequados para limitar e controlar a conduta do agent, mas, para isso, incorrerá em custos de monitoramento (monitoring costs). Da mesma forma, o principal também pode exigir que o agent contrate garantias para assegurar tanto que ele não promoverá determinadas ações que possam prejudicar o seu patrimônio quanto que o compensará em caso de danos (bonding costs).

Adicionalmente, diante dos custos despendidos, dos compromissos assumidos por cada uma das partes envolvidas e da assimetria informacional existente, pode ocorrer divergência entre elas a respeito das melhores decisões a serem tomadas, havendo, assim, uma possível perda residual (residual loss) pelo principal, referente aos recursos que potencialmente deixou de auferir (e que maximizariam a sua riqueza) por conta de desacordos com o agent.

Logo, em linha com a teoria de JENSEN \& MACKLING, em regra não se faz possível que o alinhamento de interesses do principal e do agent ocorra sem que sejam suportados determinados custos (de monitoramento e de contratação de garantias) e perdas residuais, os quais em conjunto compõem os custos de agência (agency costs).

\footnotetext{
${ }^{29}$ KRAAKMAN, Reinier et al. Ob. Cit., p. 35.

${ }^{30}$ ALLEN, Willian T. et al. Ob. Cit., p. 11.
} 
Sem prejuízo do acima exposto, vale registrar que a existência de diversos principals numa mesma relação de agência, notadamente no caso destes possuírem interesses distintos ou heterogêneos, adiciona ainda mais dificuldades a essa relação, já que os principals incorrerão, também, em custos de coordenação (coordination costs), os quais, por sua vez, vão inibir a sua atuação conjunta ${ }^{31}$. De acordo com KRAAKMAN et al, os custos de coordenação interagem com os conflitos de agência de duas maneiras:

First, difficulties of coordinating between principals will lead them to delegate more of their decision-making to agents. Second, the more difficult it is for principals to coordinate on a single set of goals for the agent, the more obviously difficult it is to ensure that the agent does the 'right' thing. Coordination costs as between principals thereby exacerbate agency problems ${ }^{32}$.

É importante notar que, a partir da definição dada pelos autores em referência, pode-se entender configurada uma relação de agência (com seus respectivos problemas e custos) sempre que houver delegação de poder ou algum tipo de esforço cooperativo entre duas ou mais pessoas ${ }^{33}$. A teoria desenvolvida por JENSEN \& MECKLING, portanto, possui ampla aplicabilidade nas mais diversas situações, ajudando a explicar, a partir de um prisma econômico, uma problemática já identificada pelo Direito, qual seja, a possibilidade de um representante utilize o seu poder para favorecimento próprio, contra os interesses do representado ${ }^{34}$.

\section{I.3. Conflitos de agência nas companhias}

Com relação às sociedades anônimas, pode-se identificar 3 (três) grupos bem distintos de interessados que orbitam o seu universo ${ }^{35}$. O primeiro deles consiste no grupo formado pelos acionistas, os quais

\footnotetext{
${ }^{31}$ KRAAKMAN, Reinier et al. Ob. Cit., p. 36.

${ }^{32}$ Ibid., pp. 36-37.

${ }^{33}$ Nesse sentido, JENSEN \& MECKLING inclusive citam que, em linha com a ampla acepção por eles conferida, haveria uma relação de agência entre os dois enquanto coautores de um mesmo artigo.

${ }^{34} \mathrm{O}$ art. 117 do Código Civil, por exemplo, estabelece ser anulável, salvo permissão legal ou do representado, o negócio jurídico que o representante, no seu interesse ou por conta de outrem, celebrar consigo mesmo. "Este dispositivo", de acordo com TEPEDINO et al, funda suas raízes no princípio da vedação ao chamado autocontrato". TEPEDINO, et al. Código Civil Interpretado Conforme a Constituição da República, $2^{\mathrm{a}}$ Ed. Rio de Janeiro: Renovar, 2007, p. 239.

${ }^{35}$ Ibid., p. 28.
} 
investem na companhia na expectativa de obter retorno de seu capital por meio da distribuição de proventos e da valorização das ações. O segundo compõe-se pelos administradores, que são contratados para gerir a sociedade e cujas remunerações advêm dos salários e outros benefícios auferidos em razão dos serviços prestados em favor da companhia. O terceiro grupo, por sua vez, abrange os demais stakeholders que de alguma maneira possuem relação com a companhia, dentre os quais destacam-se os seus credores, empregados e consumidores.

De início, portanto, constata-se dessas relações a presença de dois forçosos conflitos de agência no seio das sociedades anônimas. Em primeiro (e mais evidente) lugar, há o conflito que se coloca entre os acionistas, de um lado, e os administradores da companhia, de outro. Nesse caso, o grupo de acionistas, ocupando a posição de principal na relação de agência, busca meios de evitar que os administradores, enquanto agents, apropriem-se de bens e oportunidades comerciais da companhia, bem como que atuem com o precípuo fim de elevar sua própria remuneração, em detrimento dos interesses dos acionistas ${ }^{36}$. Em segundo lugar, há o conflito entre a própria companhia e os terceiros que com ela se relacionam. Aqui, como asseveram KRAAKMAN et al, "the difficulty lies in assuring that the firm, as agent, does not behave opportunistically toward these various other principals - such as expropriating creditors, exploiting workers, or misleading consumers" 37 .

Note-se que, como sustentado por EASTERBROOK \& FISCHEL, dado o princípio de igualdade existente entre os detentores de ações de mesma espécie e classe, bem como o princípio de que as decisões assembleares são, em regra, tomadas por maioria de $\operatorname{votos}^{38}$, os acionistas

\footnotetext{
${ }^{36}$ A propósito, em casos tais, como salienta FAN: “[...] the presence of a controlling shareholder is beneficial to the minority shareholders because the controlling shareholder can easily hold the directors accountable to the shareholder group and his large stake holding will make him motivated to make the company profitable". FAN, Chunyan. Ob. Cit., p. 24.

${ }^{37}$ KRAAKMAN, Reinier et al. Ob. Cit., p. 36.

${ }^{38}$ Ambos princípios estão presentes no direito societário brasileiro, respectivamente nos arts. 109,
} 
em geral deveriam ser vistos como um grupo coeso e homogêneo, posto que os interesses de todo o grupo estariam alinhados ${ }^{39}$.

Pode-se, no entanto, vislumbrar diversas hipóteses de alteração de cenário de harmonia, sendo relevante para fins deste trabalho a existência um indivíduo ou grupo de indivíduos que consigam, em razão da quantidade de ações detidas (ou, melhor, de votos conferidos por essas ações), de forma predeterminada e não eventual, ditar os rumos da companhia sem a necessidade de efetivamente aguardar as deliberações das assembleias gerais de acionistas, que em essência se tornam palco de ratificação de decisões anteriormente tomadas.

Nesse contexto, é importante mencionar que a preponderância de companhias com estrutura acionária dispersa, situação suscitada por BERLE \& MEANS em $1932^{40}$, a partir do estudo do quadro acionário de companhias norte-americanas, ainda não se encontra presente em diversos países. Ao contrário, estudos mais recentes indicam que, afora o próprio Estados Unidos da América e o Reino Unido, a estrutura acionária das companhias ao redor do mundo continua a ser concentrada nas mãos de famílias ou do próprio Estado ${ }^{41}$. E, especificamente no que concerne ao Brasil, vale relembrar que, em 1987, com fundamento em estudo empírico, EIZIRIK tachou de mito a ideia de que existiria controle gerencial em nosso país $^{42}$, cenário este que, embora seguramente distinto do atual, ainda se mantém relativamente presente, em especial no que concerne às companhias cujas ações não estão listadas no segmento diferenciado de

$\S 1^{\circ}$, e 129 , da Lei $n^{\circ} 6.404$, de 1976.

${ }^{39}$ EASTERBROOK; Frank H.; FISCHEL, Daniel R. The Economic Structure of Corporate Law. Cambridge: Harvard University Press, 1996, p. 70.

${ }^{40}$ BERLE, Adolf. A.; MEANS, Gardiner C. A Moderna Sociedade Anônima e a Propriedade Privada. São Paulo: Nova Cultural, 1987, p. 33.

${ }^{41}$ Nesse sentido, LA PORTA et al examinaram a estrutura acionária das vinte companhias abertas mais negociadas em vinte e sete países e descobririam que em poucas delas havia dispersão acionária, bem como que os acionistas controladores atuavam ativamente na gestão das sociedades. LA PORTA, Rafael et al. Corporate Ownership Around the World. Disponível em $<$ http://www.nber.org/papers/w6625>. Acesso em 27 de abril de 2016.

${ }^{42}$ EIZIRIK, Nelson Laks. O Mito do "Controle Gerencial”: Alguns Dados Empíricos. Revista de Direito Mercantil Industrial, Econômico e Financeiro, São Paulo, ano XXVI, n. 66, abril-junho, 1987, pp. 103-104. 
governança corporativa denominado Novo Mercado ${ }^{43}$.

Diante da predominância na assembleia geral decorrente das ações que possui, o acionista controlador consegue influenciar sobremaneira os rumos da sociedade, havendo, assim, o risco que se utilize desse seu poder a fim de favorecer a ele próprio, em prejuízo dos demais acionistas. A título de ilustração, tome-se como exemplo o seguinte caso hipotético, mencionado por FAN, que revela de modo simples uma das formas que podem ser utilizadas pelo controlador para se beneficiar em transações com a companhia:

[...] if a $80 \%$ shareholder is selling a piece of property to the company and the fair price is $\$ 100$, by setting the price at $\$ 120$ he will gain $\$ 20$ extra profit as the seller; for the $\$ 20$ loss suffered by the company, he only needs to bear $\$ 16$ as a shareholder. Since his gain as creditor of the company is more than enough to cover his loss as a shareholder of the company, it is very likely that he might choose to over-price the property and use his controlling power to force the company to accept the transaction ${ }^{44}$.

Tem-se, assim, que, ao lado dos dois conflitos de agência relacionados às companhias anteriormente mencionados (acionistas v. administradores; e companhia v. outros interessados), põe-se mais um, entre os acionistas controladores, de um lado, e os acionistas não controladores, de outro, o qual ganha substancial relevância nos países em que há forte concentração na base de acionistas das companhias ${ }^{45}$.

\footnotetext{
43 Conforme a $11^{\mathrm{a}}$ edição do estudo A Governança Corporativa e o Mercado de Capitais: um panorama atual das empresas abertas com base nos seus Formulários de Referência (2016/2017), elaborado pela KPMG, 66\% das 124 companhias listadas no Novo Mercado possuem controle majoritário ou compartilhado, situação também presente em $90 \%$ das 21 companhias do Nível 2, 96\% das 28 companhias do Nível 1, e 86\% das 50 companhias listadas no segmento tradicional de negociação. Disponível em <https://assets.kpmg.com/content/dam/kpmg/br/pdf/2016/12/brestudo-governanca-corporativa-2016-2017-11a-edicao-final.pdf>. Acesso em 23 de abril de 2017.

${ }^{44}$ FAN, Chunyan. Ob. Cit., p. 23.

45 Por outro lado, vale frisar que esse conflito, em princípio, apenas apareceria em situações específicas, considerando que, como também salienta FAN, "because of the principle of equality of shares, usually the interests of all shareholders are aligned with each other; intra-shareholder conflicts only arise when there is a chance for the controlling shareholder to extract some nonproportional benefit from the company, either through a related transaction, or some significant changes of the company that will result in a re-distribution of the interests among the shareholders. In other words, if, and only if, there is a possibility of non-proportional distribution of corporate assets, a conflict of interests between the controlling shareholder and the minority shareholder might arise". Ibid., p. 115.
} 


\section{I.4. Estratégias de controle dos custos de agência}

\section{l.4.1. Visão geral}

Como demonstra estudo de KRAAKMAN et al sobre as normas que regem as sociedades anônimas nos Estados Unidos, no Reino Unido, na Alemanha, na França, na Itália e no Japão, muitas são as estratégias utilizadas com o escopo de regular o comportamento potencialmente oportunista do agent, a fim de otimizar a eficiência econômica da relação de agência. Essas estratégias são esquematizadas da seguinte forma pelos referidos pesquisadores ${ }^{46}$ :

\begin{tabular}{|c|c|c|c|c|c|}
\hline & \multicolumn{2}{|c|}{ Estratégias regulatórias } & \multicolumn{3}{|c|}{ Estratégias de governança } \\
\hline & Controle & $\underline{\text { Associacãa }}$ & $\underline{\text { Nomeacão }}$ & Decisão & Incentivo \\
\hline Ex Ante & Regras & Entrada & Seleção & Iniciação & Trusteeship \\
\hline$\underline{\text { Ex Post }}$ & Standards & Saída & Remoção & Veto & Recompensa \\
\hline
\end{tabular}

Enquanto as estratégias regulatórias são de natureza prescritiva, ditando termos a serem seguidos pelos próprios agents quando de sua atuação (agent-constraining), as estratégias de governança têm por precípua finalidade facilitar o controle da conduta dos agents por parte dos principals (principal-empowering). Por isso, para serem eficientes aos fins a que se propõem, as estratégias de governança dependem da habilidade de organização daqueles que compõem o grupo dos principals na relação de agência, circunstância que esbarra nos custos de coordenação anteriormente mencionados. A eficácia das estratégias regulatórias, por seu turno, sujeitase a precondições distintas:

Most obviously, they depend for efficacy on the ability of an external authority a court or a regulatory body - to determine whether or not the agent complied with particular prescriptions. This requires not only good-quality regulatory institutions - the hallmarks of which are expertise and integrity - but effective disclosure mechanisms to ensure that information about the actions of agents can be 'verified' by the regulator ${ }^{47}$.

\footnotetext{
${ }^{46}$ KRAAKMAN, Reinier et al. Ob. Cit., p. 39.

${ }^{47}$ Ibid., p. 38.
} 
Note-se que, adicionalmente à divisão das estratégias entre regulatórias e de governança, a outra categorização proposta por KRAAKMAN et al as separa em táticas com aplicação ex ante ou ex post à atuação do agent. Essa segunda sistematização, no entanto, como salientam os próprios autores, não deve ser tida como absoluta, na medida em que, na prática, as estratégias de redução dos custos de agência têm, em alguma medida, aplicabilidade nos dois momentos ${ }^{48}$.

Conforme exposto na Introdução, o presente trabalho tem por enfoque a análise na aplicação de standards, mas, antes de melhor explicar suas diferenças com as regras, cumpre resumidament ne expor no que consistem as estratégias regulatórias de associação, bem como as estratégias de governança de nomeação, decisão e de incentivo.

\section{I.4.2. Estratégias regulatórias de associação}

Em suma, as estratégias de associação envolvem a regulação dos termos segundo os quais os agents e os principals podem entrar ou sair da relação de agência. No primeiro caso, pode-se de exigir dos agents a disseminação de determinadas informações julgadas relevantes antes do início da relação, enquanto no segundo é possível a conferência de certos direitos aos principals para que estes, em dadas situações, retirem-se dessa relação.

No contexto societário, a exigência de divulgação de informações pela companhia aos seus investidores constitui exemplo de uma estratégia regulatória de associação referente à entrada dos participantes na relação de agência. Ressalve-se, todavia, que, segundo DAVIES, a exigência de full disclusure, máxima que norteia toda a regulação do mercado de capitais, deve ser categorizada como um tipo especial de estratégia para a redução dos custos de agência, posto que consiste em "such an important strategy

${ }^{48}$ Ibid., p. 44. 
that is needed in the application of all other strategies" ${ }^{\prime 9}$.

Ao seu turno, como estratégia de saída pode-se mencionar a existência do direito de retirada, garantido em poucas e excepcionais situações aos acionistas que, seja por meio do voto contrário, da abstenção ao direito de voto ou mesmo do não comparecimento a dada assembleia, dissentem de determinadas deliberações que tem por condão alterar de forma substancial as bases sobre as quais se fundamenta a companhia, bem como o próprio equilíbrio acionário.

Como se nota, tanto as estratégias de entrada como as de saída são adotadas em nosso ordenamento jurídico. No que tange às primeiras, inúmeras são as regras, contidas na lei societária brasileira e nas instruções emitidas pela CVM, que demandam a divulgação completa e contínua de diversas informações, cabendo citar, a título de ilustração, a necessidade de divulgação de informações periódicas e eventuais (arts. 21 e seguintes da Instrução CVM no 480, de 2009) e de atos ou fatos relevantes (art. 157, §4 da Lei ${ }^{\circ}$ 6.404, de 1972, e arts. $2^{\circ}$ e seguintes da Instrução CVM n 358 , de $2002)^{50}$.

Com relação às segundas, a lei societária brasileira confere a oportunidade de os acionistas descontentes com determinadas deliberações tomadas em assembleias retiraram-se da companhia, mediante o reembolso de suas ações (art. 45 da Lei $n^{\circ}$ 6.404, de 1976), como ocorre, por exemplo, no caso de aprovação da mudança do objeto social (art. 136, VI e art. 137, caput, da Lei $n^{\circ}$ 6.404, de 1976) ou de inserção de convenção de arbitragem no estatuto social (art. 136-A da Lei $n^{\circ} 6.404$, de 1976).

\section{I.4.3. Estratégias de governança}

As estratégias de governança de nomeação, além de conferirem à

49 DAVIES, Paul L. Apud FAN, Chunyan. Ob. Cit., p. 30. Diz FAN: "Without sufficient information, the principal cannot evaluate the agent's performance, let alone make sensible decision as to how to use those strategies to protect his own interests. (...) Since it is an all-time necessity, disclosure is not treated as an independent strategy". Ob. Cit., p. 30.

${ }^{50}$ Tal como ocorre nas jurisdições estudadas por KRAAKMAN, Reinier et al, a legislação do mercado de capitais brasileira também está alicerçada na regra do full disclosure. 
generalidade dos acionistas discricionariedade na eleição e destituição dos administradores das companhias, também facilitam a eleição de administradores por determinados grupos específicos de principals (em especial acionistas minoritários e empregados da companhia), seja por meio da reserva de um ou mais assentos nos órgãos de deliberação da companhia a representantes desses grupos, seja pelo estabelecimento de mecanismos especiais de votação que visem a facilitação de sua eleição.

Como exemplo, cite-se que, no Brasil, a Lei ${ }^{\circ}$ 6.404, de 1976, estabelece, em seu art. 122, inciso II, que, ressalvado o disposto no art. 142, inciso II, desse diploma legal, compete privativamente à assembleia geral eleger ou destituir, a qualquer tempo, os administradores e conselheiros fiscais da companhia. O art. 141, caput, da Lei $\mathrm{n}^{\circ}$ 6.404, de 1976, por sua vez, rege o chamado voto múltiplo, por meio do qual se atribui a cada ação tantos votos quantos sejam os membros do conselho de administração, havendo permissão expressa para a cumulação de votos num mesmo

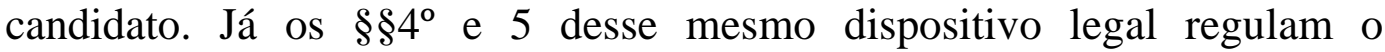
procedimento pelo qual acionistas minoritários das companhias podem eleger membros para o Conselho de Administração em separado, e o parágrafo único do art. 140 da lei em voga permite ao estatuto social a previsão de participação no conselho de administração de representantes dos empregados da companhia.

Com relação às estratégias de governança de decisão, tem-se que buscam garantir aos principals o poder de iniciar, ratificar ou vetar determinadas deliberações pelos agents. Essas táticas, embora relevantes, tornam-se muito custosas no contexto societário, principalmente porque a companhia é pensada como veículo para delegação da gestão empresarial aos administradores, de modo que, em regra, apenas decisões mais relevantes e que tenham o condão de afetar sobremaneira os fundamentos da sociedade requerem a aprovação ou posterior ratificação pelos 
$\operatorname{acionistas}^{51}$.

Assim como ocorre com as demais estratégias, as de governança de decisão também estão presentes no arcabouço jurídico brasileiro. $\mathrm{O}$ art. 122, inciso VIII, da Lei $n^{\circ}$ 6.404, de 1976, por exemplo, reserva à assembleia geral a competência para deliberar sobre a transformação, fusão, incorporação ou cisão da companhia. Do mesmo modo, a aquisição do controle de qualquer sociedade mercantil depende de prévia autorização da assembleia geral ou de sua ratificação sempre que presentes determinadas circunstâncias de relevância ou de montante envolvido na operação, nos termos do art. 256 da Lei $n^{\circ}$ 6.404, de 1976. Ademais, a escolha e a destituição dos auditores independentes estão sujeitas a veto fundamentado dos membros do conselho de administração eleitos em separado pelos acionistas da companhia (art. 142, §2º da Lei n ${ }^{\circ}$ 6.404, de 1976).

Por fim, por meio da última categoria de estratégias de governança a de incentivo -, ao invés de se aumentar o poder de controle dos principals sobre os agents, tenta-se alterar os incentivos destes, tanto pela garantia de benefícios monetários - quando da conformidade de sua atuação e dos bons retornos financeiros aos principals (recompensa) - como pela atenuação ex ante dos potenciais conflitos existentes entre os integrantes da relação de agência (trusteeship). No âmbito societário, recorre-se, via de regra, para o primeiro caso, a planos de opções de ações com o fim de alinhar os interesses dos administradores com os dos acionistas, bem como, para o segundo caso, aos chamados conselheiros independentes, com a expectativa de que estes, em função de sua esperada imparcialidade, guiem suas condutas norteados tão somente por suas consciências e reputações ${ }^{52}$.

Como destacam KRAAKMAN et al, nenhuma jurisdição impõe, por força legal ou regulamentar, a adoção desses mecanismos, mas tão somente criam as condições para a sua implementação pelas sociedades,

\footnotetext{
${ }^{51}$ KRAAKMAN, Reinier et al. Ob. Cit., p. 42.

${ }^{52}$ Ibid., p. 43.
} 
encorajando-as $^{53}$. O mesmo ocorre no Brasil, onde se permite, como estratégia de recompensa, que o estatuto preveja a outorga de opção de compra de ações a seus administradores (art. 168, $\S 3^{\circ}$, da Lei n ${ }^{\circ} 6.404$, de 1976). Por sua vez, o principal exemplo das estratégias de governança baseadas em trusteeship no país encontra-se no regulamento do Novo Mercado da Brasil Bolsa Balcão - $3^{54}$, que exige, para a listagem da companhia, a presença de, no mínimo, 20\% de conselheiros independentes no respectivo conselho de administração ${ }^{55}$.

\section{I.4.4. Estratégias regulatórias de controle}

A principal e mais conhecida estratégia de redução de custos de agência consiste em controlar a conduta do agent, ordenando-o que não atue de forma a causar prejuízos aos interesses do principal. Isso pode ser feito com o uso de regras, que de modo específico e prévio proíbem o agent de realizar determinado comportamento (controle ex ante), ou, então, por meio de standards de conduta, os quais genericamente demandam que o agent adote certa postura e deixam para um momento posterior a aferição de conformidade ou não de sua atuação ao padrão predeterminado (controle expost).

"Rules draw a clear-cut line between what can be done and what cannot”, como resume FAN, "while standards only give a general guide

${ }^{53}$ Ibid., p. 43.

54 Disponível em < http://www.bmfbovespa.com.br/pt br/listagem/acoes/segmentos-delistagem/novo-mercado/>. Acesso em 26 de abril de 2017.

55 Conforme o disposto no citado regulamento de listagem, o conselheiro independente "caracteriza-se por: (i) não ter qualquer vínculo com a Companhia, exceto participação de capital; (ii) não ser Acionista Controlador, cônjuge ou parente até segundo grau daquele, ou não ser ou não ter sido, nos últimos 3 (três) anos, vinculado a sociedade ou entidade relacionada ao Acionista Controlador (pessoas vinculadas a instituições públicas de ensino e/ou pesquisa estão excluídas desta restrição); (iii) não ter sido, nos últimos 3 (três) anos, empregado ou diretor da Companhia, do Acionista Controlador ou de sociedade controlada pela Companhia; (iv) não ser fornecedor ou comprador, direto ou indireto, de serviços e/ou produtos da Companhia, em magnitude que implique perda de independência; (v) não ser funcionário ou administrador de sociedade ou entidade que esteja oferecendo ou demandando serviços e/ou produtos à Companhia, em magnitude que implique perda de independência; (vi) não ser cônjuge ou parente até segundo grau de algum administrador da Companhia; e (vii) não receber outra remuneração da Companhia além daquela relativa ao cargo de conselheiro (proventos em dinheiro oriundos de participação no capital estão excluídos desta restrição)". 
and leave room for the agent to exercise his discretion" "56. Assim, no caso de uma legislação que vise a diminuir acidentes nas estradas por excesso de velocidade, por exemplo, enquanto as regras estabeleceriam limites de velocidade aos motoristas, os standards de conduta determinariam que eles tivessem cuidado e prudência ao dirigir ${ }^{57}$.

Em favor do uso de regras pesam a certeza, a uniformidade, a estabilidade e a segurança de sua aplicação, mas em desfavor a intransigência com as circunstâncias de cada caso, a excessiva codificação, a rigidez e a possibilidade de fácil superação com o decorrer do tempo. Por seu lado, os standards de conduta são positivos por conta de sua flexibilidade, individualização, renovação e dinamismo, mas negativos porque seu uso pode ser manipulado e as decisões tomadas podem ser contraditórias, além de prevalecer a indeterminação sobre a correção ou não do comportamento adotado até a manifestação do órgão responsável por realizar essa avaliação ${ }^{58}$.

Diante de sua rigidez e da complexidade das atividades empresariais, o controle ex ante da conduta dos agents com o uso de regras proibitivas possui limitações na conjuntura societária ${ }^{59}$. Assim sendo, as relações internas das sociedades anônimas tendem a ser regidas por meio de standards de comportamento abertos, deixando-se para um momento posterior a aferição da lisura ou não da atuação dos agents, sejam eles administradores ou acionistas controladores ${ }^{60}$. Como se percebe, no que respeita às sociedades anônimas, o principal exemplo do uso de estratégia regulatória baseada em standards está nos deveres fiduciários impostos aos administradores $^{61-62}$.

\footnotetext{
${ }^{56}$ FAN, Chunyan. Ob. Cit., p. 39.

57 Ibid., p. 40.

${ }^{58}$ SCHLAG, Pierre J. Rules and Standards.

Disponível em <https://lawweb.colorado.edu/profiles/pubpdfs/schlag/schlagUCLALR.pdf>. Acesso em 26 de abril de 2017.

${ }^{59}$ KRAAKMAN, Reinier et al. Ob. Cit., pp. 39-40.

${ }^{60}$ Ibid., p. 40

${ }^{61}$ Ibid., p. 78.
} 
No Brasil, pode-se dizer que também há uma certa preferência da lei societária pelo uso de standards para regular a conduta dos diversos agents inseridos no seio das companhias, em comparação com o uso de regras de proibição, conforme voto proferido pelo então Diretor da CVM Pedro Marcílio:

Estratégia de Proibição. Consiste na proibição de operações concretas ou na estipulação de termos e condições obrigatórios ou proibidos para certos negócios e operações. A Lei 6.404/76 utiliza pouco essa estratégia, especialmente em seu texto original. Após as reformas sofridas, ela foi utilizada, por exemplo, na proibição de emissão de partes beneficiárias pelas companhias abertas ${ }^{63}$.

No que toca aos administradores, por exemplo, a Lei $n^{\circ} 6.404$, de 1976, estipula que estes devem exercer suas funções com cuidado e diligência (art. 153), de forma leal (art. 155) e visando a lograr os fins e no interesse da companhia (art. 154), conceitos abertos cuja concreção depende das circunstâncias envolvidas em cada caso concreto ${ }^{64}$. A propósito, a própria Exposição de Motivos da Lei n 6.404, de 1976, menciona que os artigos do diploma legal em questão enumeram quase que pedagogicamente os deveres e responsabilidades dos administradores, fixando-lhes padrões de comportamento ${ }^{65}$.

Ao acionista controlador, por sua vez, a Lei $\mathrm{n}^{\circ}$ 6.404, de 1976,

\footnotetext{
${ }^{62}$ Registre-se que, sob o prisma econômico, os assim denominados deveres fiduciários, comumente subdivididos em deveres de diligência e lealdade, são impostos em resposta aos altos custos de agência que seriam necessários caso se pretendesse regular contratualmente a conduta dos administradores. Nesse sentido, dizem EASTERBROOK \& FISCHEL: "Instead of specific undertakings, the agent assumes a duty of loyalty in pursuit of the objective and a duty of care in performance. These legal duties reflect both the nature of the principal's choice (he is hiring expertise) and an obvious condition (the principal is unwilling to put himself at the mercy of an agent whose effort and achievements are both exceedingly hard to monitor). (...) So, we concluded, a "fiduciary" relation is a contractual one characterized by unusually high costs of specification and monitoring. (...) Fiduciary duties are not special duties; they have no moral footing; they are the same sort of obligations, derived and enforced in the same way, as other contractual undertaking". EASTERBROOK \& FISCHEL. Ob. Cit., pp. 426-427.

${ }^{63}$ Processos CVM RJ2006/7204 e RJ2006/7213, Rel. Dir. Pedro Oliva Marcílio de Souza, julg. em $17 / 10 / 2006$

${ }^{64}$ Com efeito, até mesmo nos dispositivos em que se veda ao administrador a realização de determinadas condutas a lei societária brasileira acaba por recorrer, em parte, aos standards, como se observa, a título ilustrativo, no art. 156 da Lei $\mathrm{n}^{\circ}$ 6.404, de 1976. A despeito de proibir o administrador de intervir nas deliberações em que tenha interesse conflitante com a companhia, o referido comando não define em que hipóteses essa situação restaria configurada, deixando para os julgadores o juízo de valor sobre a existência ou não de conflito de interesses em cada caso concreto.

${ }^{65}$ Exposição de Motivos no 196, de 24 de junho de 1976, do Ministério da Fazenda.
} 
prescreve o dever de usar o poder de controle com o fim de fazer a companhia realizar seu objeto e cumprir sua função social, e, além disso, a lei societária lhe impõe deveres e responsabilidades para com os demais acionistas da empresa, os que nela trabalham e para com a comunidade em que atua, destacando, ainda, a necessidade de respeito e atendimento aos direitos e interesses desses grupos (art. 116, parágrafo único).

\section{I.5. Rules or Standards?}

Em decorrência dos custos empregados na manutenção de uma ampla posição concentrada em ações de uma mesma companhia, bem como dos gastos incorridos no monitoramento dos administradores, o recebimento de certa quantidade de benefícios privados é, em certa medida, necessário para induzir o acionista controlador a exercer essa função ${ }^{66}$. Na mesma linha, os benefícios privados do controle, por serem intransferíveis, criam incentivos para que o acionista controlador, ao invés de liquidar seu investimento no mercado, permaneça com as ações da companhia por longo período, assim contribuindo para que ele se preocupe com a reputação e a performance da sociedade no longo prazo $^{67}$.

O ponto nodal concernente aos benefícios privados de controle, portanto, diz respeito à sua quantidade: a extração desses benefícios tornase aceitável para os acionistas não controladores até a exata medida em que as perdas suportadas em sua decorrência igualem ou superem o montante economizado com a desnecessidade deles próprios incorrerem em custos de agência para o controle da ação dos administradores.. No entanto, o que ultrapassar esse limite passa a ser descontado pelos investidores do preço dos valores mobiliários emitidos pela companhia, reduzindo o seu valor.

Por conta disso, conjuntamente com a boa qualidade das informações

\footnotetext{
${ }^{66}$ GILSON, Ronald J.; GORDON, Jeffrey N. Controlling Controlling shareholders. Disponível em <http://papers.ssrn.com/abstract=417181 >. Acesso em 27 de abril de 2017.

${ }^{67}$ CHOI, Albert H. Costs and Benefits of Concentrated Ownership and Control. Disponível em $<$ https://papers.ssrn.com/sol3/papers.cfm?abstract_id=2619462>. Acesso em 27 de abril de 2017.
} 
disponíveis aos investidores, um mercado de capitais desenvolvido depende de estes plenamente confiarem que os administradores e acionistas controladores das companhias investidas não os expropriarão de grande parte ou de todo o valor de seu investimento ${ }^{68}$. E, não por outro motivo, estudos comparativos demonstram que a alta extração de benefícios privados de controle e a proteção ineficiente dos investidores estão associadas a mercados menos desenvolvidos e a maior concentração acionária $^{69}$.

Conforme anteriormente mencionado, existem, em essência, três formas pelas quais o acionista controlador consegue extrair benefícios privados decorrentes do poder de controle por ele detido: (i) as transações com partes relacionadas; (ii) a alienação do poder de controle com prêmio; e (iii) a diminuição, por meio de operações societárias, da participação dos acionistas minoritários no quadro acionário da companhia.

Com o decorrer do tempo, deixou-se de utilizar regras proibitivas para a regulação dessas transações. No entanto, como afirmam KRAAKMAN et al, todas as jurisdições por eles estudadas impõem standards para o controle ex post de transações potencialmente não equitativas no âmbito do conflito entre acionistas controladores e não controladores $^{70}$. A mudança no sistema regulatório, antes pautado fundamentalmente em estratégias de proibição nas mais diversas jurisdições, foi assim explicada pelo Diretor da CVM Pedro Marcílio:

Os dois motivos básicos para essa evolução é que, no mais das vezes, todas as operações sociais podem ser benéficas aos acionistas e à companhia, a depender dos termos propostos, e ninguém melhor do que eles (ou representantes seus) para saber o que é melhor para eles nos casos concretos. A proibição atingiria, portanto, operações benéficas.

Intervenções estatais (sejam pelo Poder Judiciário ou por órgãos como a CVM)

${ }^{68}$ BLACK, Bernard S. Legal and Institutional Preconditions for Strong Securities Markets. 48 UCLA Law Review, v. 781, 2001, p. 783.

69 Vide DYCK, Alexander; ZINGALES, Luigi. Private Benefits of Control: An International Comparison. The Journal of Finance, v. LIX, n. 2, abril de 2004, p. 589. No mesmo sentido, vide LA PORTA, Rafael. et al. Ob. Cit., p. 2.

${ }^{70}$ KRAAKMAN, Reinier et al. Ob. Cit., p. 173. 
tendem a produzir piores resultados do que a atuação direta dos acionistas (ou de administradores desinteressados), por falta de conhecimento específico da companhia e da situação vivida pelos próprios acionistas. Além disso, é muito difícil mensurar se a estratégia de proibição efetivamente protege os acionistas não controladores ou apenas cria restrições temporárias aos acionistas controladores, até que encontrem soluções alternativas para a exploração dos acionistas não controladores ${ }^{71}$.

A propósito, insta também consignar que, em análise específica sobre o tema, GILSON \& SCHWARTZ concluem que o controle ex post dos benefícios privados extraídos pelo controlador por parte de juízes especializados em direito societário, como nos Estados Unidos, possui as seguintes vantagens sobre o seu controle ex ante, estratégia que, segundo os autores, é a mais utilizada pelos países da União Europeia:

First, ex post transactional review allows control structures that have the potential to provide better monitoring and hence better performance than a B\&M [BERLE $\&$ MEANS]-style company. Second, by capping the amount of PBC [private benefits of control] through effective judicial review, the lemons problem of companies having to pay through the cost of capital for excessive PBC is avoided. Companies could make credible commitments to efficient levels of PBC. Third, by allowing some range of $\mathrm{PBC}$ - the "in the range of reasonableness" measure - corporations can secure the benefits of a controlling shareholder's more effective monitoring when it is efficient ${ }^{72}$.

Os padrões de comportamento atribuídos aos acionistas controladores recebem diversas nomenclaturas ao redor do mundo. Por exemplo, nos Estados Unidos, como se verá em mais detalhes no próximo capítulo, diz-se que os controladores são fiduciários ${ }^{73}$; na França, proíbe-se o abuso de maioria ${ }^{74}$; e, na China, veda-se o abuso de direitos dos acionistas, o que se faz especialmente aplicável aos controladores ${ }^{75}$.

"Como se evidencia das lições de direito comparado", concluem LAMY FILHO \& BULHÕES PEDREIRA, "a nomenclatura variada das figuras jurídicas com que se assegura a proteção da minoria não obscurece

\footnotetext{
${ }^{71}$ Processos CVM RJ2006/7204 e RJ2006/7213, Rel. Dir. Pedro Oliva Marcílio de Souza, julg. em $17 / 10 / 2006$.

${ }^{72}$ GILSON, Ronald. J; SCHWARTZ, Alan. Constraints on Private Benefits of Control: Ex Ante Control Mechanisms versus Ex Post Transaction Review. Journal of Institutional and Theoretical Economics, v. 169, ed. 1, 2013, p. 181.

${ }^{73}$ Ibid., p. 173.

${ }^{74}$ Ibid., p. 174.

${ }^{75}$ FAN, Chunyan. Ob. Cit., p. 197.
} 
o fato de que são todas afins, buscando os mesmos efeitos" ${ }^{76}$. No mesmo sentido, para KRAAKMAN et al, "whatever the labels and the details, these doctrines have a similar thrust: unfair related-party transactions are unlawful and it is for the courts to determine unfairness after the fact"77.

Cumpre esclarecer, por fim, que há uma substancial diferença entre os padrões de comportamento (standards of conduct) e os modos pelos quais esses comportamentos serão avalizados (standards of review ou standards of liability). Em poucas palavras, EISENBERG explica que " $a$ standard of conduct states how an actor should conduct a given activity or play a given role", enquanto, por outro lado, "a standard of review states the test a court should apply when it reviews an actor's conduct to determine whether to impose liability or grant injunctive relief' 78 .

Em regra, esses dois tipos de standards são análogos. Assim, a título ilustrativo, se o standard of conduct que norteia os motoristas prescreve que estes devem dirigir cuidadosamente, em uma eventual ação de responsabilidade civil o Poder Judiciário verificará se determinado motorista cumpriu de modo satisfatório esse comando ${ }^{79}$.

Por razões que fogem ao escopo do presente trabalho, essa regra encontra diversas exceções no direito societário. É certo, no entanto, que, no caso de uma estratégia de controle baseada em padrões de comportamento, o modo pelo qual essa conduta é aferida é mais relevante para o seu êxito do que a definição em si do padrão de comportamento ${ }^{80-81}$.

\footnotetext{
${ }^{76}$ LAMY FILHO, Alfredo; BULHÕES PEDREIRA, José Luiz. Ob. Cit., p. 868.

${ }^{77}$ KRAAKMAN, Reinier et al. Ob. Cit., p. 173.

${ }^{78}$ EISENBERG, Melvin Aron. The Divergence of Standards of Conduct and Standards of Review in Corporate Law. Fordham Law Review, v. 62, 1993, p. 437.

${ }^{79}$ Ibid., p. 437.

${ }^{80}$ FAN, Chunyan. Ob. Cit., p. 50.

${ }^{81}$ GILSON, Ronald. J; SCHWARTZ, Alan. Ob. Cit., p. 165.
} 


\section{CAPÍTULO II. O MODELO NORTE-AMERICANO}

Expostos, no capítulo anterior, no que consistem os conflitos de agência no âmbito das companhias e os custos deles decorrentes, bem como os motivos pelos quais o uso de standards no controle da atuação do acionista controlador possui vantagens comparativamente à utilização de regras proibitivas, passa-se a demonstrar, neste capítulo, o modo pelo qual essa estratégia é adotada pelo Poder Judiciário dos Estados Unidos da América, em especial pelas cortes do estado de Delaware, no contexto de reestruturações societárias que envolvem o acionista controlador da companhia.

\section{II.1. Definição de acionista controlador}

Em 1987, por ocasião do julgamento do caso Ivanhoe Partners $v$. Newmont Mining Corp. ${ }^{82}$, a Suprema Corte de Delaware decidiu que um acionista somente assume o papel de controlador "if [he] owns a majority or exercises control over the business affairs of the corporation". A partir desse precedente, consolidou-se na jurisprudência de Delaware a distinção entre as figuras dos chamados controladores de jure e de facto.

Considera-se controlador de jure o acionista ou grupo de acionistas que detiverem mais de 50\% das ações da companhia. Nessa hipótese, vale frisar, não há a necessidade de que o sócio efetivamente exerça o controle para lhe sejam atribuídos os deveres correspondentes, porque, diante da percepção de que o poder de controle muitas vezes opera de modo sutil, entende-se que não se faz possível inteiramente negar a possibilidade de o acionista majoritário influenciar na gestão da sociedade ${ }^{83}$.

Desde que possua o poder concreto de direcionar as atividades da companhia, o acionista que não detém a maioria do capital votante da

\footnotetext{
${ }^{82}$ Ivanhoe Partners v. Newmont Mining Corp, 535 A.2d 1334 (Del. 1987).

${ }^{83}$ Nessa esteira, conclui FAN: "Delaware law, therefore, will not ask whether or not the majority shareholder actually exercised his control over corporate affairs before imposing a fiduciary duty upon him". FAN, Chunyan. Ob. Cit., p. 68.
} 
companhia igualmente pode ser caracterizado como controlador (de facto $)^{84}$. Por não haver uma escala de participação acionária que evidencie prima facie se um acionista é ou não o controlador ${ }^{85}$, recai sobre o autor o ônus de provar o exercício desse poder pelo réu numa ação em que se questione os atos do suposto controlador ${ }^{86}$.

Ressalte-se, ademais, que diversos acionistas com participações minoritárias podem ser considerados conjuntamente como integrantes de um grupo controlador, sendo-lhes, assim, atribuídos os respectivos deveres decorrentes dessa posição. Contudo, para que seja configurada uma relação entre esses acionistas, o autor da ação deve demonstrar que eles possuem alguma conexão, bem como que atuam com o fim de alcançar objetivos comuns. Não basta, assim, a mera existência de concorrência de interesses para se evidenciar a presença de um grupo de controle ${ }^{87}$.

\section{II.2. Standard of conduct: o controlador como fiduciário}

As decisões de cortes norte-americanas atribuindo ao acionista controlador o papel de fiduciário, com a consequente cominação dos deveres advindos dessa posição, datam ao menos desde a década de $1880^{88}$, existindo registros de que a doutrina daquele país avalizava essa visão já no

\footnotetext{
84 "For controlling stock ownership to exist in the absence of a numerical majority there must be domination by a minority shareholder through actual exercise of direction over corporate conduct". Gilbert v. El Paso Co, 490 A.2d 1050 (Del. Ch. 1984). No mesmo sentido, Citron v. Fairchild Camera Instrument, 569 A.2d 53 (Del. 1989).

85 “. [...] the cases do not reveal any sort of linear, sliding-scale approach whereby a larger share percentage makes it substantially more likely that the court will find the stockholder was a controlling stockholder. Instead, the scatter-plot nature of the holdings highlights the importance and fact-intensive nature of the actual control factor. [...] These cases show that a large blockholder will not be considered a controlling stockholder unless they actually control the board's decisions about the challenged transaction". In Re Crimson Exploration Inc., Civil Action No 8541-VCP (Del. Ch. Oct. 24, 2014).

86 "When a stockholder owns less than $50 \%$ of the corporation's outstanding stock, "a plaintiff must allege domination by a minority shareholder through actual control of corporate conduct." The bare conclusory allegation that a minority stockholder possessed control is insufficient". In Re Morton's Rest. Grp., Inc., 74 A.3d 656 (Del. Ch. 2013).

${ }^{87}$ In Re Crimson Exploration Inc., Civil Action No 8541-VCP (Del. Ch. Oct. 24, 2014).

${ }^{88}$ MACINTOSH, Jeffrey G. et al. The Puzzle of Shareholder Fiduciary Duties. Canadian Business Law Journal, V. 19, 1991, p. 87.
} 
início do Século $\mathrm{XX}^{89}$.

Foi, contudo, em 1919, a partir do julgamento do caso Southern Pacific Co. v. Bogert ${ }^{90}$ pela Suprema Corte dos Estados Unidos, que o entendimento de que os acionistas controladores possuem deveres fiduciários ganhou substancial notoriedade. Por sua relevância para o tema deste trabalho, vale descrever, ainda que sucintamente, os fatos que circundaram o referido precedente.

A Southern Pacific controlava indiretamente a Houston Railway, a qual, por sua vez, detinha a maioria do capital votante de outra sociedade, a Houston. Em 1887, no âmbito de reorganização societária, foi firmado um acordo que previa a extinção de hipotecas sobre propriedades da Houston e a consequente aquisição de tais bens pela Houston Railway, o que ocorreu no ano seguinte. Em seguida, foram emitidas novas ações pela Houston, as quais foram todas entregues à Southern Pacific, que também incorporou em seu patrimônio as linhas ferroviárias transnacionais pertencentes à sua controlada indireta, de sorte que os acionistas minoritários da Houston nada receberam pela operação.

Quando do julgamento da ação judicial interposta por acionistas minoritários da Houston, em 1913, a Suprema Corte de Nova York, em decisão posteriormente ratificada pela Corte de Apelação, determinou que a Southern Pacific entregasse aos minoritários uma parte das ações emitidas pela companhia por ocasião da reestruturação societária, bem como certa quantia em dinheiro referente aos proventos distribuídos no período.

Após aceitar revisar o caso, a Suprema Corte dos Estados Unidos manteve a decisão recorrida. E, no julgamento, o Justice Brandeis externou

\footnotetext{
89 “ $[\ldots]$ the holders of a majority of the stock of a corporation cannot force a sale of all the corporate property to themselves, or to another corporation in which they are interested for its value, when they know that a better price can be obtained - even though the sale be unassailable in equity and be made in strict accordance with the law. Such an act, though proper in every other sense, constitutes the violation of a fiduciary duty". CARRINGTON, Richard W. The Status of Stockholders Relative to the Internal Affairs of Corporations. Virginia Law Review, v. 5, n. 1, 1917, p. 50.

${ }^{90}$ Southern Pacific Co. v. Bogert, 250 U.S. 483 (U.S. 1919).
} 
a opinião daquele tribunal nos seguintes dizeres:

The minority stockholders do not complain of a wrong done the corporation or of any wrong done by it to them. They complain of the wrong done them directly by the Southern Pacific and by it alone. The wrong consists in its failure to share with them, the minority, the proceeds of the common property of which it, through majority stockholdings, had rightfully taken control. In other words, the minority assert the right to a pro rata share of the common property; and equity enforces the right by declaring the trust on which the Southern Pacific holds it and ordering distribution or compensation. The rule of corporation law and of equity invoked is well settled and has been often applied. The majority has the right to control; but when it does so, it occupies a fiduciary relation toward the minority, as much so as the corporation itself or its officers and directors. If through that control a sale of the corporate property is made and the property acquired by the majority, the minority may not be excluded from a fair participation in the fruits of the sale ${ }^{91}$.

Poucos anos depois, em 1923, a Suprema Corte de Delaware expôs juízo similar ao julgar o caso Allied Chemical \& Dye Corporation v. Steel \& Tuve Co. of America et. al ${ }^{92}$ :

The same considerations of fundamental justice which impose a fiduciary character upon the relationship of the directors to the stockholder will also impose, in a proper case, a like character upon the relationship which the majority of the stockholders bear to the minority. When, in the conduct of corporate business, a majority of the voting power in the corporation join hands in imposing its policy upon all, [...] they are to be regarded as having placed upon themselves the same sort of fiduciary character which the law impresses upon the directors in their relation to all shareholders.

Muito embora seja reconhecido que ao controlador aplicam-se princípios colidentes, na medida em que, de um lado, como qualquer outro acionista, lhe é garantido o direito de usufruir das ações que possui em seu exclusivo interesse, mas, de outro, dele se exige especial consideração com os demais acionistas ${ }^{93}$, é firme a conclusão de que, após as referidas

\footnotetext{
${ }^{91}$ Grifos do autor.

${ }^{92}$ Allied Chemical \& Dye Corporation v. Steel \& Tuve Co. of America et. al, 120 A. 486 (Del. Ch. 1923).

${ }^{93}$ Como expõe SIEGEL: "The law governing controlling-shareholder transactions is predicated on two competing considerations. On the one hand, shareholders who own a sizable percentage of stock have bought stock solely because they believed the purchase to be in their self-interest. Cognizant of this fact, courts have sanctioned the right of all shareholders to vote in their own interest' and generally to retain the sole right to any control premium when they sell their stock. On the other hand, courts recognize that these shareholders have significant, if not decisive, voting power; that power could skew decisions disproportionately in their favor because of their ability to elect and remove the board of directors. As a result, Delaware courts have placed controlling shareholders under the fiduciary duty rubric in order to be able to constrain their ability to selfdeal". SIEGEL, Mary. The Erosion of the Law of Controlling Shareholders. Delaware Journal of
} 
decisões, a caracterização dos acionistas controladores como fiduciários tornou-se um consenso na jurisprudência norte-americana ${ }^{94}$.

Há, porém, quem critique duramente esse entendimento ${ }^{95}$, em especial no que se refere à quase equiparação que muitas vezes se conjectura entre os deveres dos acionistas controladores e dos administradores ${ }^{96}$. Como mencionam ALLEN et al, a imposição de deveres fiduciários aos controladores foi apenas um pequeno passo dado pelas cortes após o entendimento de que os administradores possuem tais deveres $^{97}$. A teoria, assim, não foi desenvolvida especificamente para os acionistas controladores; ela foi meramente estendida e, quando muito, adaptada.

A propósito, cabe mencionar que até mesmo a passagem mais citada para expressar o entendimento de que o acionista controlador deve ser considerado um fiduciário, articulada ainda na década de 1940, segue esse (criticado) caminho. Em Pepper v. Litton" ${ }^{98}$ disse o Justice Douglas: “A diretor is a fiduciary. So is a dominant or controlling stockholder or group

Corporate Law, v. 24, n. 1, 1999, pp. 32-34.

94 "The tenor of the federal decisions in respect to the general fiduciary duty of those in control of a corporation is unmistakable." Zahn v. Transamerica Corporation, 162 F.2d 36, 42 (3d Cir. 1947). "[There is a] judicial consensus (in the United States) that a controlling shareholders owe a duty of fairness to minority shareholders in the exercise of corporate powers [...]". ALLEN, William T. et al. Ob. Cit., p. 309. "Unlike the English approach, case law in the United States has recognized the existence of a fiduciary duty incumbent on controlling shareholders". COHEN, Zipora. Fiduciary Duties of Controlling Shareholders: A Comparative View. University of Pennsylvania Journal of International Law, v. 12, 1991, p. 387.

${ }^{95}$ Para DALLEY: “Controlling stockholders' fiduciary duties are a judicial invention stimulated by a desire to provide relief to minority stockholders who later regretted their own or their decedent's bargains and encouraged by scholars advocating a neo-marxist view of investing. Although such duties have been enforced in some jurisdictions for a quarter-century, they continue to be poorly understood and undertheorized. Even a cursory examination of the offered justifications for such duties reveals the weaknesses of such justifications. More importantly, a reasoned understanding of fiduciary duties reveals that they are both unnecessary and inappropriate restrictions on a stockholder's freedom to act". DALLEY, Paula J. The Misguided Doctrine of Stockholder Fiduciary Duty. Hostra Law Review, v. 33, ed. 1, 2004, p. 176.

96 "The notion, however, that directors and controlling shareholders have identical fiduciary duties is squarely in conflict with Delaware's case law on the controlling shareholder's duty of loyalty". DAMMANN, Jens. The Controlling Shareholder's General Duty of Care: A dogma That Should Be Abandoned. University of Illinoius Law Review, n. 2, 2015, p. 504.

${ }^{97}$ ALLEN, Willian T. et al, p. 309.

${ }^{98}$ Pepper v. Litton, 308 U.S. 295 (U.S. 1939). Citações omitidas. 
Os críticos da teoria que considera os acionistas controladores como fiduciários ressaltam que essa posição, em verdade, apenas pode ser atribuída a alguém que, por meio de delegação, direta e efetivamente administre o patrimônio de outrem, função esta que, no âmbito das sociedades anônimas, cabe tão-somente aos administradores, e não aos acionistas, em geral, ou mesmo aos controladores, em particular ${ }^{99}$.

Entretanto, esse potencial problema teórico não parece abalar a firme convicção sobre o assunto existente na jurisprudência norte-americana, principalmente porque a análise dos deveres do controlador sempre é realizada levando-se em consideração as características de cada caso concreto $^{100}$. É, ademais, igualmente pacífico o entendimento de que dos controladores não se exige o sacrifício de seus próprios interesses econômicos ${ }^{101}$, pelo que eles estão livres para vetar as operações que não desejem, mesmo aquelas que possam ser especialmente vantajosas para os acionistas minoritários $^{102}$.

\footnotetext{
99 "Although the nature of fiduciary relationships is largely undertheorized, fiduciary duties tend to arise where someone is acting on another's behalf and has been given power or authority in order to accomplish the purpose of the relationship. That situation does not generally exist between stockholders in a normally functioning corporation. A stockholder is not expected to act on behalf of either the corporation or the other stockholders; in fact, stockholders lack the power to do so. Similarly, there is no delegation of power to stockholders. Stockholders' limited powers, which involve only voting, are their own; they are incidents of the ownership of shares and are not delegated by anyone. The other stockholders retain their own, identical, powers. As discussed above, in a corporation officers and directors, not stockholders, meet the criteria for fiduciaries". DALLEY, Paula J., Ob. Cit., p. 208.

${ }^{100}$ FAN, Chunyan. Ob. Cit., p. 77.

101"While the law requires that corporate fiduciaries observe high standards of fidelity and, when self-dealing is involved, places upon them the burden of demonstrating the intrinsic fairness of transactions they authorize, the law does not require more than fairness. Specifically, it does not, absent a showing of culpability, require that directors or controlling shareholders sacrifice their own financial interest in the enterprise for the sake of the corporation or its minority shareholders". Jedwab v. MGM Grand Hotels, Inc, 509 A.2d 584 (Del. Ch. 1986).

102 "In other words, there was nothing here that distinguishes this case from the long-standing rule that a controller does not have to entertain offers. That this is the case, of course, does not mean that the controller or its affiliates are immune from claims for the improper exercise of fiduciary power. If the controller attempts to squeeze out the minority, cause the controlled entity to engage in interested transactions, or other such conduct, the duty of loyalty operates to police the controller's conduct. But a mere refusal of a controller to allow the entity to be sold does not support a cause of action against it or its affiliated directors". Buttonwood Tree Value Partners, Lp v. Sullivan, 126 A.3d 643 (Del. 2015). Grifos do autor.
} 
De todo modo, se a assertiva do Justice Douglas é verdadeira, e assim se entende na jurisprudência norte-americana, especialmente em Delaware, também não se pode negar, noutro giro, que ela, por sua vagueza, nada responde. Afinal, como posto, com propriedade, pelo Justice Frankfurter,

[...] to say that a man is a fiduciary only begins analysis; it gives direction to further inquiry. To whom is he a fiduciary? What obligations does he owe as a fiduciary? In what respect has he failed to discharge these obligations? And what are the consequences of his deviation from duty? ${ }^{103}$

As duas últimas questões citadas pelo Justice Frankfurer, como se percebe, não podem ser respondidas de forma genérica, vez que certamente dependem das circunstâncias específicas de cada caso. Pode-se, contudo, tentar responder as outras duas indagações, ou, ao menos, buscar esclarecer alguns de seus aspectos.

No tocante a primeira pergunta ("To whom is he a fiduciary?"), cabe primeiramente consignar que, em linha com o que sustentam ALLEN et al, a importância de endereçar com precisão a dúvida sobre os destinatários dos deveres dos "fiduciários", sejam eles controladores ou administradores, pode em muitos casos parecer mais teórica do que prática ${ }^{104}$. Entretanto, a relevância dessa definição exsurge notadamente nos momentos em que a companhia se encontra em estágio de insolvência, quando, por definição, há dificuldades econômicas para honrar todas as obrigações exigíveis ${ }^{105}$. Nesse cenário, distintos desfechos podem surgir a depender de quem se entenda ser o beneficiário primário dos deveres dos administradores e controladores.

Nada obstante, com relação aos acionistas controladores, a definição dos destinatários de seus deveres fiduciários é incerta. Enquanto algumas decisões descrevem que o acionista controlador possui deveres para com a

\footnotetext{
103 Securities Comm'n v. Chenery Corp, 318 U.S. 80 (U.S. 1943).

${ }^{104}$ ALLEN, William T. et al Ob. Cit., p. 296.

105 Ibid., p. 296.
} 
própria companhia, e não aos demais acionistas ${ }^{106}$, outras salientam que as obrigações do acionista controlador são diretamente direcionadas aos minoritários $^{107}$, havendo até mesmo precedentes que indicam que, por ocasião de falência de uma companhia, "[the] fiduciary obligation is designed for the protection of the entire community of interests in the corporation - creditors as well as stockholders" ${ }^{\prime 108}$.

Embora a maioria dos julgados somente descreva os deveres do controlador sem maiores detalhamentos sobre os seus beneficiários ${ }^{109}$, pode-se dizer que, desde as primeiras decisões sobre o assunto, como se verifica até mesmo dos precedentes antes mencionados, "the ultimate purpose of imposing the duty has been to protect minority shareholders against the possible harm inflicted upon them by the controlling shareholders" $" 110$.

Quanto à segunda indagação levantada pelo Justice Frankfurter (“What obligations does he owe as a fiduciary?"), a Court of Chancery de Delaware afirmou o que se segue quando da apreciação do caso Cinerama, Inc. v. Technicolor, Inc. ${ }^{111}$ :

When a shareholder, who achieves power through the ownership of stock, exercises that power by directing the actions of the corporation, he assumes the duties of care and loyalty of a director of the corporation. When, on the other hand, a majority shareholder takes no such action, generally no special duty will be imposed.

A respeito, apesar de existir aparente consenso na jurisprudência e doutrina norte-americanas no que concerne à aplicação de um dever de diligência genérico aos acionistas controladores, a imposição dessa obrigação, conforme bem expõe DAMMANN, não parece ser necessária na

\footnotetext{
${ }^{106}$ DALLEY, Paula J. Ob. Cit., p. 183.

107 Jones v. H.F. Ahmanson Co, 1 Cal.3d 93(Cal. 1969).

108 Pepper v. Litton, 308 U.S. 295(U.S. 1939).

${ }^{109}$ DALLEY, Paula J. Ob. Cit., p. 183.

${ }^{110}$ FAN, Chunyan. Ob. Cit., p. 76.

111 Cinerama, Inc. v. Technicolor, Inc., Civ. A. No. 8358, 1991 WL 111134 (Del. Ch. June 24, 1991), aff'd in part, rev'd on other grounds sub nom. Cede \& Co. v. Technicolor, Inc., 634 A.2d 345 (Del. 1993).
} 
maior parte dos casos, por uma simples razão: ao contrário do que ocorre com relação aos administradores, o retorno econômico do capital investido por quaisquer dos acionistas depende essencialmente do lucrativo desenvolvimento das atividades empresariais da companhia.

Sob esse prisma, uma vez que, dentre os acionistas, os controladores são aqueles que, em regra, possuem a maior quantidade de capital investido na companhia, "they already have strong financial incentives to make informed decisions in the best interest of their corporations, making it unnecessary to impose a duty requiring them to do so"112. E, de fato, como conclui FAN,

It is not that controlling shareholders do not need to act with care; rather, it is just not necessary to hold controlling shareholders to a judicially enforced standard. In most cases, controlling shareholder have a strong incentive to exercise their power with care; otherwise they themselves suffer the severest loss ${ }^{113}$.

Não por outro motivo, até onde se sabe ${ }^{114}$, há apenas uma situação concreta em que se concluiu que os acionistas controladores poderiam ser responsabilizados por infração ao seu dever de diligência ${ }^{115}$, qual seja, no contexto de alienação do controle de uma companhia para terceiro que o controlador sabe - ou, em razões das circunstâncias, deveria saber - ser um looter, isto é, alguém que pretende adquirir o controle de determinada companhia somente com o intuito de alienar os seus bens ${ }^{116}$.

Em casos tais, como reconhecido até mesmo por DAMMANN, os incentivos dos controladores podem não ser suficientes para estimulá-los a

\footnotetext{
${ }^{112}$ DAMMANN, Jens. Ob. Cit., p. 481.

${ }^{113}$ FAN, Chunyan. Ob. Cit., p. 77.

${ }^{114}$ Vide: DAMMANN, Jens. Ob. Cit., p. 492; FAN, Chunyan. Ob. Cit., p. 177; e ALLEN, William T. et al. Ob. Cit., p. 429.

${ }^{115}$ Nesse sentido, em Harris v. Carter, a Court of Chancery, seguindo a opinião do Chancellor Allen, decidiu que: "Thus, I conclude that while a person who transfers corporate control to another is surely not a surety for his buyer, when the circumstances would alert a reasonably prudent person to a risk that his buyer is dishonest or in some material respect not truthful, a duty devolves upon the seller to make such inquiry as a reasonably prudent person would make, and generally to exercise care so that others who will be affected by his actions should not be injured by wrongful conduct". Harris v. Carter, 582 A.2d 222 (Del. Ch. 1990).

116 "Under the looting doctrine, a controlling shareholder violates his fiduciary duties when he negligently sells his controlling stake to an apparent looter, who indeed then proceeds to plunder ("loot") the corporation". DAMMANN, Jens. Ob. Cit., p. 492.
} 
tomar decisões informadas e refletidas, na medida em que a espoliação dos bens da companhia pelo looter somente se inicia após a alienação do controle, momento em que os antigos controladores já não mais sofrerão as consequências desses atos ${ }^{117}$.

Não obstante, para além de sua aparente desnecessidade na maior parte dos casos, o estudo aprofundado do dever de diligência dos acionistas controladores também não apresenta muitas justificativas, ao menos não no direito norte-americano. É que, em linha com o que se entende com relação à atuação dos administradores, os atos (desinteressados) do acionista controlador também estão protegidos pela chamada business judgment rule, presumindo-se que este atua "in good faith and inspired by a bona fides of purpose ${ }^{, 118}$.

A propósito, até mesmo na ocasião da alienação do controle a terceiros, entende-se que, afora naturalmente os casos de dolo, os controladores somente podem ser responsabilizados nas situações em que gravemente tenham negligenciado (gross negligence) em descobrir que o adquirente se tratava de um looter ${ }^{119}$, o que corrobora a visão de que a atribuição de um dever de diligência genérico aos acionistas controladores possui caráter mais retórico do que prático.

Assim, seja considerando-se a business judgment rule como um standard of review, em linha com o defendido por EISENBERG ${ }^{120}$, seja vendo-a como uma doutrina de abstenção que impede os juízes de revisar o

\footnotetext{
${ }^{117}$ DAMMANN, Jens. Ob. Cit., p. 493.

118 "In the absence of divided interests, the judgment of the majority stockholders and/or the board of directors, as the case may be, is presumed made in good faith and inspired by a bona fides of purpose”. David J. Greene v. Dunhill Int'l, 249 A.2d 427 (Del. Ch. 1968).

119 "In so concluding I assume without deciding that a duty of care of a controlling shareholder that may in special circumstances arise in connection with a sale of corporate control is breached only by grossly negligent conduct". Harris v. Carter, 582 A.2d 222 (Del. Ch. 1990). No mesmo sentido, decidiu-se, em Abraham v. Emerson Radio Corp, que: "At the very least, a plaintiff seeking to state a claim must plead facts that indicate that the controller knew there was a risk that the buyer was a looter or otherwise intended to extract illegal rents from the subsidiary, at the expense of the subsidiary's remaining stockholders". Abraham v. Emerson Radio Corp, 901 A.2d 751 (Del. Ch. 2006).

${ }^{120}$ EISENBERG, Melvin A. Ob. Cit., p. 438.
} 
mérito das decisões tomadas, como descreve BAINBRIDGE ${ }^{121}$, fato é que essa regra, quando não afastada, impede a responsabilização judicial dos acionistas controladores.

Contrariamente ao dever de diligência, porém, como alegoricamente citam ANABTAWI \& STOUT, "the fiduciary duty of loyalty has real teeth" ${ }^{122}$. Esse dever, em essência, dita que os interesses da companhia e de seus acionistas devem prevalecer sobre qualquer outro interesse, detido pelo conselheiro, diretor ou acionista controlador, que não seja compartilhado pela generalidade dos acionistas ${ }^{123}$.

Em outras palavras, como destacam ALLEN et al - para quem "the core of fiduciary doctrine is the duty of loyalty"

The duty of loyalty requires a corporate director, officer, or controlling shareholder to exercise her institutional power over corporate process or property (including information) in good-faith effort to advance the interests of the company. Stated negatively, the duty of loyalty requires interests such a person who transacts with the corporation's to fully disclose all material facts to the corporation's disinterested representatives and to deal with the company on terms that are intrinsically fair in all respects. Thus, corporate officers, directors, and controlling shareholders may not deal with the corporation in any way that benefits themselves at its expense ${ }^{125}$.

O dever de lealdade assume especial relevância na jurisprudência norte-americana nos casos em que os controladores possuem algum interesse particular em determinada transação, bem como nas situações relacionadas a mudanças de fundamentos estruturais da companhia, em especial quando, de alguma maneira, resultam na saída forçada dos

121 Como explica BAINBRIDGE, existem duas visões principais sobre a natureza da business judgment rule. Na primeira - e mais aceita -, entende-se o preceito como um stantard of review, que, para uns, protege os conselheiros que atuam em boa fé e, para outros, eleva a "liability bar" de mera negligência para níveis mais altos de culpabilidade, como a negligência grave (gross negligence). Na segunda visão, entretanto, a business judgment rule é entendida como uma doutrina de abstenção que estabelece uma presunção contra a revisão judicial do mérito das decisões dos administradores, a qual somente pode ser afastada se o autor da ação provar que o administrador não atuou de boa-fé. BAINBRIDGE, Stephen M. The Business Judgment Rule as Abstention Doctrine. Disponível em <http://ssrn.com/abstract=429260>. Acesso em 30 de abril de 2017.

${ }^{122}$ ANABTAWI, Iman; STOUT, Lynn A. Fiduciary Duties For Activist Shareholders. Stanford Law Review, vol. 60, 2008, p. 12

${ }^{123}$ Tradução de excerto contido em Cede Co. v. Technicolor, Inc, 634 A.2d 345, 361 (Del. 1993).

${ }^{124}$ ALLEN, William T. et al. Ob. Cit., p. 295.

125 Ibid., p. 295. 
acionistas minoritários do quadro acionário (freeze-out $)^{126}$.

Em hipóteses como as supramencionadas ${ }^{127}$, não mais se aplica a valiosa - e quase insuperável - proteção da business judgment rule, mas sim o standard of review denominado entire fairness. Com isso, surge para os próprios controladores o dever de comprovar que a operação foi inteiramente justa para os minoritários, recaindo sobre eles, assim, o ônus de provar a plena equitatividade da transação ${ }^{128}$.

Com o fim de melhor explicar esse preceito, no próximo tópico serão explicados os elementos considerados pelas cortes norte-americanas para aferir se determinada operação de fato atende aos dois elementos que conjuntamente compõem o entire fairness: preço justo (fair price) e processo justo de negociação (fair dealing). Explorar-se-á, ademais, em mais detalhes, as operações que estão sujeitas a esse standard of review.

\section{II.3. Standard of review: o entire fairness test}

\section{II.3.1. As facetas do entire fairness test}

Ainda que as referências ao entire fairness test sejam recorrentes ao menos desde o início do Século $\mathrm{XX}^{129}$, foi em 1983, no julgamento do caso

\footnotetext{
${ }^{126}$ Como sumarizado por RUDER, as seguintes situações são aquelas que tendem a ser enfatizadas pelos autores ao tratar do dever de lealdade dos administradores e acionistas controladores: (i) transações com a companhia; (ii) operações entre companhia controladora e controlada; (iii) imposição de prejuízos aos acionistas minoritárias em aquisições e reorganizações societárias; (iv) remuneração excessiva dos administradores; (v) uso do patrimônio da companhia para manutenção do controle; (vi) alienação do controle com prêmio; (vii) insider trading; e (viii) uso de oportunidades comerciais. RUDER, David S. Duty of Loyalty: A Law Professor's Status Report. The Business Lawyer, Vol. 40, N. 4, 1985, pp. 1386-1387.

${ }^{127}$ No próximo tópico serão descritas as situações que estão submetidas à análise do entire fairness.

128 'Plaintiffs' principal contention here, as in the court below, is that the terms of the merger are unfair to Mayflower's minority stockholders. Plaintiffs invoke the settled rule of law that Hilton as majority stockholder of Mayflower and the Hilton directors as its nominees occupy, relation to the minority, a fiduciary position in dealing with Mayflower's property. Since they stand on both sides of the transaction, they bear the burden of establishing its entire fairness, and it must pass the test of careful scrutiny by the courts". Sterling, Et Al., v. Mayflower Hotel Corp., Et Al, 33 Del. Ch. 293 (Del. 1952). Grifos do autor.

129 "The relation of directors to corporations is of such a fiduciary nature that transactions between boards having common members are regarded as jealously by the law as are personal dealings between a director and his corporation, and where the fairness of such transactions is challenged the burden is upon those who would maintain them to show their entire fairness and where a sale is involved the full adequacy of the consideration. Especially is this true where a common director is
} 
Weinberger v. UOP, Inc. ${ }^{130}$ ("Weinberger"), que a Suprema Corte de

Delaware definiu a questão como atualmente posta na jurisprudência norteamericana $^{131}$. Ao expor a decisão do mencionado tribunal, o Justice Moore traduziu o conceito de fairness nas seguintes linhas:

The concept of fairness has two basic aspects: fair dealing and fair price. The former embraces questions of when the transaction was timed, how it was initiated, structured, negotiated, disclosed to the directors, and how the approvals of the directors and the stockholders were obtained. The latter aspect of fairness relates to the economic and financial considerations of the proposed merger, including all relevant factors: assets, market value, earnings, future prospects, and any other elements that affect the intrinsic or inherent value of a company's stock. However, the test for fairness is not a bifurcated one as between fair dealing and price. All aspects of the issue must be examined as a whole since the question is one of entire fairness. However, in a non-fraudulent transaction we recognize that price may be the preponderant consideration outweighing other features of the merger ${ }^{132}$.

\section{II.3.1.1. Preço justo (fair price)}

Exigir que determinada transação seja realizada por seu preço justo significa dizer, em essência, que os acionistas controladores devem garantir que a companhia e seus acionistas minoritários recebam uma compensação cujo valor seja equivalente àquilo que deles foi retirado ${ }^{133}$.

Ao se verificar se uma determinada transação atende ao requisito do preço justo, que consiste no elemento material (substantive fairness) do entire fairness test, devem ser considerados todos os fatores, presentes ou futuros, que podem influenciar nesse valor ${ }^{134}$. Mas, em linha com o

dominating in influence or in character. This court has been consistently emphatic in the application of this rule, which, it has declared, is founded in soundest morality, and we now add in the soundest business policy". Geddes v. Anaconda Mining Co, 254 U.S. 590 (U.S. 1921).

${ }^{130}$ Weinberger v. Uop, Inc, 457 A.2d 701 (Del. 1983).

${ }^{131}$ Como afirmado pelo Justice Jacobs em palestra proferida na Universidade de Harvard, até o julgamento de Weinberger, o conceito de entire fairness "was amorphous and open-ended-that is, it lacked specific content that facilitated predicting the outcome of litigation-until 1983. Not until Weinberger v. UOP, Inc. did the Delaware Supreme Court gave the practicing bar and the courts more detailed procedural guidance and a clearer analytical framework for determining whether a conflicted transaction is entirely fair". JACOBS, Jack B. Fifty Years of Corporate Law Evolutiion: A Delaware Judge Retrospective. Harvard Business Law Review, V. 5, Ed. 2, 2015, p. 155.

${ }^{132}$ Citações omitidas.

${ }^{133}$ FAN, Chunyan. Ob. Cit., p. 79.

${ }^{134}$ Weinberger v. Uop, Inc, 457 A.2d 701 (Del. 1983). 
decidido em Sterling, Et Al., v. Mayflower Hotel Corp. ${ }^{135}$,

[...] the requirement that consideration be given to all relevant factors entering into the determination of value does not mean that any one factor is in every case important or that it must be given a definite weight in the evaluation. The relative importance of several tests of value depends on the circumstances.

Nesse sentido, saliente-se que, em Weinberger, a Suprema Corte de Delaware decidiu que o método de valuation denominado "Delaware Block" não deveria ser mais o único aceitável pelas cortes judiciais daquele estado, pelo que passou-se a adotar, a partir do referido precedente, " $a$ more liberal approach [that] must include proof of value by any techniques or methods which are generally considered acceptable in the financial community and otherwise admissible in court"136. Cabe registrar, por outro lado, que, qualquer que seja a metodologia utilizada, ela deve avaliar a companhia na premissa de que a sociedade está e permanecerá em atividade (going concern assumption), não podendo ser considerado isoladamente o seu valor de liquidação ${ }^{137}$.

\section{II.3.1.2. Processo justo de negociação (fair dealing)}

Como visto, em Weinberger afirmou-se que um processo justo de negociação (fair dealing), que representa o elemento processual do entire fairness test (procedural fairness), abrange tanto questões relativas à sua estruturação (timing, iniciação e negociação) quanto questões relacionadas à sua divulgação e aprovação pelos conselheiros e acionistas.

Sobre o primeiro aspecto do fair dealing, deve-se salientar que Weinberger foi determinante para impulsionar o uso de comitês especiais independentes para negociar as operações que envolvem controladoras e controladas. Em uma multicitada nota de rodapé (de $\left.n^{\circ} 7\right)$, a decisão da Suprema Corte de Delaware alertou para o seguinte:

Although perfection is not possible, or expected, the result here could have been entirely different if UOP had appointed an independent negotiating committee of

\footnotetext{
135 Sterling, Et Al., v. Mayflower Hotel Corp., Et Al, 33 Del. Ch. 293 (Del. 1952).

${ }^{136}$ Weinberger v. Uop, Inc, 457 A.2d 701 (Del. 1983)

137 "In Delaware a company is valued as a going concern, not on what can be obtained by its liquidation." Rosenblatt v. Getty Oil Co, 493 A.2d 929 (Del. 1985).
} 
its outside directors to deal with Signal at arm's length. Since fairness in this context can be equated to conduct by a theoretical, wholly independent, board of directors acting upon the matter before them, it is unfortunate that this course apparently was neither considered nor pursued. Particularly in a parentsubsidiary context, a showing that the action taken was as though each of the contending parties had in fact exerted its bargaining power against the other at arm's length is strong evidence that the transaction meets the test of fairness $^{138}$.

Para que se demonstre que a transação foi negociada numa situação de arm's length devem estar presentes três requisitos ${ }^{139}$. O primeiro é a presença de pessoas independentes que negociem a operação com o acionista controlador (em geral, administradores da própria controlada). $\mathrm{O}$ segundo, por sua vez, é a ausência de imposição forçada dos termos da operação aos minoritários, bem como de coação desses acionistas ou dos membros do comitê especial por parte do controlador. O terceiro, por fim, é o exercício concreto pelo comitê especial independente de seu poder de barganha, o qual deve necessariamente incluir o "direito de dizer "não", ou seja, a possibilidade de vetar definitivamente a operação.

A respeito da composição do comitê especial, cumpre mencionar que o entendimento jurisprudencial norte-americano presume que todos os membros do conselho de administração são independentes, ainda que esses administradores tenham sido eleitos pelos controladores ${ }^{140}$. Por conta disso, conforme os precedentes de Delaware, cabe ao autor da ação indicar em sua petição inicial elementos concretos capazes de colocar em xeque a independência dos conselheiros integrantes do comitê:

To show that a director is not independent, a plaintiff must demonstrate that the director is "beholden" to the controlling party "or so under [the controller's] influence that [the director's] discretion would be sterilized." Our law is clear that mere allegations that directors are friendly with, travel in the same social circles, or have past business relationships with the proponent of a transaction or the person they are investigating, are not enough to rebut the presumption of independence. Rather, the Supreme Court has made clear that a plaintiff seeking

\footnotetext{
${ }^{138}$ Citações omitidas. Grifos do autor.

${ }^{139}$ FAN, Chunyan. Ob. Cit., p. 83.

140 "[...] it is not enough to charge that a director was nominated by or elected at the behest of those controlling the outcome of a corporate election. That is the usual way a person becomes a corporate director. It is the care, attention and sense of individual responsibility to the performance of one's duties, not the method of election, that generally touches on independence". Aronson $v$. Lewis, 473 A.2d 805 (Del. 1984).
} 
to show that a director was not independent must meet a materiality standard, under which the court must conclude that the director in question's material ties to the person whose proposal or actions she is evaluating are sufficiently substantial that she cannot objectively fulfill her fiduciary duties. Consistent with the overarching requirement that any disqualifying tie be material, the simple fact that there are some financial ties between the interested party and the director is not disqualifying. Rather, the question is whether those ties are material, in the sense that the alleged ties could have affected the impartiality of the director. Our Supreme Court has rejected the suggestion that the correct standard for materiality is a "reasonable person" standard; rather, it is necessary to look to the financial circumstances of the director in question to determine materiality ${ }^{141}$.

$\mathrm{O}$ segundo aspecto do fair dealing relaciona-se notadamente às informações que são divulgadas sobre a operação aos conselheiros, aos acionistas minoritários e aos membros do comitê especial, se existente. A jurisprudência de Delaware demanda que todos os fatos e circunstâncias com conteúdo material que circundam a operação devem ser divulgadas ${ }^{142}$, considerando-se uma informação material "if there is substantial likelihood that a reasonable shareholder would consider it in deciding how to vote ${ }^{143}$.

Em Delaware, o entendimento predominante indica que não cabe ao juiz averiguar a suficiência das informações disponíveis aos minoritários para avaliar se o dever de full disclosure foi ou não respeitado, devendo sua análise centrar-se tão-somente na comparação objetiva entre as informações materiais detidas pelos controladores e aquelas que foram por eles divulgadas aos minoritários, a fim de verificar se houve alguma assimetria informacional. Para utilizar das palavras da Suprema Corte do referido estado: "Completeness, not adequacy, is both the norm and the mandate under present circunstances". 144

\section{II.3.1.3. A correlação entre o fair dealing e o fair price}

Nesse ponto, faz-se necessário relembrar que a Suprema Corte de Delaware expressamente reconheceu, ao julgar Weinberger, que o elemento do preço pode ser determinante na aferição da justeza de uma operação não

\footnotetext{
${ }^{141}$ In Re MFW Shareholders Litig., 67 A.3d 496 (Del. Ch. 2013). Citações omitidas.

${ }^{142}$ Kahn v. Lynch Communication Systems, Inc., 669 A.2d 79 (Del. 1995).

${ }^{143}$ Rosenblatt v. Getty Oil Co, 493 A.2d 929 (Del. 1985).

${ }^{144}$ Lynch v. Vickers Energy Corp, 383 A.2d 278 (Del. 1977).
} 
fraudulenta, notadamente porque o que se busca, ao fim, é que ao acionista minoritário seja devolvido algo com valor equivalente àquilo que dele foi retirado. E nada mais.

Por conta disso, a ausência de um processo justo de negociação não implica necessariamente na conclusão de que a operação falhou no entire fairness, pois o teste aplicado em Delaware não é bifurcado, mas sim uno:

Therefore, the [controlling shareholder] bears the burden to prove that the merger was entirely fair. That burden has been said to require that the proponents of a conflicted merger demonstrate that they proceeded in a manner that was both procedurally and substantively fair. That is more than a bit of a misnomer, as the overriding consideration is whether the substantive terms of the transaction were fair. Thus, it has been said that the two-part fairness test is not a bifurcated one; rather, all aspects of the transaction are examined as a whole in order to aid in coming to the bottom-line conclusion of whether the transaction was fair ${ }^{145}$.

A existência de um elemento no entire fairness test referente ao processo de negociação, por outro lado, justifica-se no fato de que o valor de uma companhia não é determinado por um número exato, mas sim por uma faixa de valores ${ }^{146}$. Em operações complexas e que exijam a avaliação de diversas variáveis, portanto, um verdadeiro e efetivo processo de negociação arm's length pode ser o único modo de se definir no que consiste o preço justo. Por isso, a conclusão de que houve um real e efetivo fair dealing influencia significativamente na avaliação da justeza dos termos da operação ${ }^{147}$.

\section{II.4. A aplicação do entire fairness test}

Quando os atos que envolvem o acionista controlador devem ser escrutinados por meio da aplicação do entire fairness? Em quais situações a presunção de que o controlador atuou na persecução dos legítimos interesses da companhia, garantida pela business judgment rule, deve ser afastada? Basta que o controlador esteja em situação de conflito de interesses, controlando ambos os lados da operação, ou é necessário que se prove algum prejuízo aos demais acionistas?

\footnotetext{
${ }^{145}$ Delaware Open MRI Radiology v. Kessler, 898 A.2d 290 (Del. Ch. 2006).

${ }^{146}$ Cede Co. v. Technicolor, Inc., Civil Action No. 7129 (Del. Ch. Dec. 31, 2003).

${ }^{147}$ In re Orchard Enterprises, Inc. Stockholder Litigation, C.A. No 7840 (Del. Ch. Feb. 28, 2014).
} 
A relevância dessas perguntas não deve ser subestimada. Afinal, como assentado em Nixon v. Blackwell ${ }^{148}$,

It is often of critical importance whether a particular decision is one to which the business judgment rule applies or the entire fairness rule applies. It is sometimes thought that the decision whether to apply the business judgment rule or the entire fairness test can be outcome-determinative.

No mesmo sentido, destacou-se o seguinte em Ac Acquisitions v. Anderson $^{149}$ :

Because the effect of the proper invocation of the business judgment rule is so powerful and the standard of entire fairness so exacting, the determination of the appropriate standard of judicial review frequently is determinative of the outcome of derivative litigation.

Cabe mencionar, ademais, que a relevância da definição do standard of review, além da questão relativa à distribuição do ônus probatório, também impacta enormemente no tempo de duração do processo (e, em consequência, nos custos dele decorrentes). E isso porque, em sendo cabível a business judgment rule, veda-se a revisão da operação e a ação judicial, em regra, ou é julgada em um rito sumário ou é arquivada sem a apreciação de seu mérito, o que somente não ocorre, nesse último caso, quando os termos da operação são tão visivelmente desvantajosos que nenhuma pessoa racional e de boa-fé poderia ter pensado que o negócio fora justo ${ }^{150}$.

Ao reverso, na hipótese de cabimento do entire fairness, usualmente os processos vão a julgamento pelo rito ordinário, podendo demorar diversos anos para chegar ao fim ${ }^{151}$ - o caso Cede \& Co. v. Technicolor, Inc. ${ }^{152}$ é o mais emblemático exemplo dessa afirmativa, haja vista que seu encerramento somente ocorreu após vinte anos de litígio.

Entretanto, apesar de sua fundamental importância para o desfecho ${ }^{153}$

\footnotetext{
${ }^{148}$ Nixon v. Blackwell, 626 A.2d 1366 (Del. 1993).

${ }^{149}$ Ac Acquisitions v. Anderson, Clayton Co, 519 A.2d 103 (Del. Ch. 1986).

${ }^{150}$ In Re MFW Shareholders Litig., 67 A.3d 496 (Del. Ch. 2013).

${ }^{151}$ HAAS, Steven M. Toward a Controlling Shareholder Safe Harbor. Virginia Law Review, V. 90, N. 8, p. 2278.

${ }^{152}$ Cede Co. v. Technicolor, Inc., 7129 (del.ch. 2003), Civil Action No. 7129. (Del. Ch., 2003)

${ }^{153}$ Ressalte-se que a aplicação do entire fairness test não significa dizer que haverá uma decisão contrária ao réu, posto que ele poderá comprovar - embora por um processo longo e difícil - que a transação foi, de fato, justa. Nesse sentido, afirmou-se em Emerald Partners, v. Berlin, 787 A.2d
} 
dos processos judiciais que analisam operações envolvendo controladores e controladas, as respostas para as perguntas anteriormente expostas não são tão claras. A própria Court of Chancery de Delaware, quando do julgamento do caso Citron v. E.I. Du Pont De Nemours ${ }^{154}$, expressamente admitiu, ainda que em uma nota de rodapé, que "the precise circumstances that will trigger the 'entire fairness' standard of review have not been consistently articulated in the Delaware cases". E, não por outro motivo, já se sugeriu, em sede doutrinária, que, diante da inconsistência dos precedentes sobre o assunto em questão, a lei de Delaware referente aos acionistas controladores sofreria de um processo erosivo ${ }^{155}$.

Diante da importância do tema para o presente trabalho, cumpre revisitar em maiores detalhes ao menos dois precedentes, considerados leading cases a respeito do assunto em discussão. Em seguida, será destacado o estágio atual em que se encontra a jurisprudência norteamericana relativamente à definição do standard of review nas hipóteses de operações entre a companhia e seu acionista controlador.

\section{II.4.1. Sinclair}

Em Sinclair Oil Corporation v. Levien" 156 ("Sinclair"), um acionista minoritário da Sinclair Venezuelan Oil Company ("Sinven"), controlada da Sinclair Oil, entrou com uma ação contra a controladora, alegando que ela teria violado os seus deveres fiduciários em relação à Sinven por: (i) forçar a controlada a distribuir montante excessivo de dividendos; (ii) impedir o pleno desenvolvimento das atividades industriais da Sinven ao desviar suas oportunidades comerciais a outras companhias do grupo; e (iii) constranger a Sinven a não executar contrato que lhe garantia a possibilidade de exigir a compra de um montante mínimo de seus produtos por uma subsidiária integral da Sinclair Oil.

85: "A determination that a transaction must be subjected to an entire fairness analysis is not an implication of liability". Emerald Partners, v. Berlin, 787 A.2d 85 (Del. 2001).

${ }^{154}$ Citron v. E.I. Du Pont De Nemours Co., 584 A.2d 490, 500 n.13 (Del. Ch. 1990).

155 SIEGEL, Mary. Ob. Cit, p. 27.

${ }^{156}$ Sinclair Oil Corporation v. Levien, 280 A.2d 717 (Del. 1971). 
Ao avaliar o caso, a Court of Chancery de Delaware decidiu que a Sinclair Oil tinha deveres fiduciários para com a sua controlada Sinven, bem como que, considerando a ausência de independência dos membros do conselho de administração da Sinven com relação à Sinclair Oil (eram conselheiros, diretores ou empregados de companhias da família Sinclair), o standard of review aplicável para julgar o caso seria o entire fairness test.

A Suprema Corte de Delaware, no entanto, reformou parcialmente a decisão. Após revisitar os precedentes nos quais foram analisadas transações entre companhias controladoras e controladas, a corte afirmou que a situação básica para o uso do entire fairness seria aquela em que a controladora recebe benefícios com exclusão e às custas da controlada, concluindo que

a parent does indeed owe a fiduciary duty to its subsidiary when there are parentsubsidiary dealings. However, this alone will not evoke the intrinsic fairness standard. This standard will be applied only when the fiduciary duty is accompanied by self-dealing - the situation when a parent is on both sides of a transaction with its subsidiary. Self-dealing occurs when the parent, by virtue of its domination of the subsidiary, causes the subsidiary to act in such a way that the parent receives something from the subsidiary to the exclusion of, and detriment to, the minority stockholders of the subsidiary ${ }^{157}$.

Desse modo, segundo decidido pela Suprema Corte de Delaware, o entire fairness (ou intrinsic fairness) não caberia em todas as transações envolvendo companhias controladoras e controladas, mas tão-somente naquelas em que há self-dealing, ou seja, quando a controladora, por sua posição, tem o poder de decidir os dois lados da operação com a sua controlada. $^{158}$

No mérito, o tribunal decidiu que a distribuição de dividendos pela Sinven não poderia ser considerada self-dealing, porque, apesar de ter

\footnotetext{
${ }^{157}$ Sinclair Oil Corporation v. Levien, 280 A.2d 717 (Del. 1971).

158 Conforme expõe FAN, seguindo esse excerto de Sinclair, os seguintes quatro elementos deveriam estar presentes para a caracterização de self-dealing: (i) dominação da controlada pela controladora; (ii) ganho de algum benefício pela controladora advindo da controlada; (iii) exclusão dos acionistas minoritários da controlada do benefício obtido pela controladora; e (iv) prejuízo dos acionistas minoritários da controlada em decorrência do benefício obtido pela controladora. FAN, Chunyan. Ob. Cit., p. 108.
} 
havido uma massiva transferência de dinheiro para a Sinclair Oil, os dividendos foram recebidos de forma proporcional pelos acionistas minoritários da Sinven e, assim, "Sinclair received nothing from Sinven to the exclusion of its minority stockholders". Por conta disso, a corte determinou que a Corte de Chancelaria se equivocou ao aplicar o entire fairness, pois a business judgment rule seria o standard of review correto para o caso.

À mesma conclusão chegou o tribunal a respeito do segundo ponto levantado pelo autor da ação, pois ele não teria conseguido comprovar que oportunidades comerciais pertencentes à Sinven teriam dela sido desviados para a Sinclair Oil ou para outras de suas controladas. Assim, concluiu-se que "Sinclair received nothing from Sinven to the exclusion of and detriment to Sinven's minority stockholders, there was no self-dealing".

Por outro lado, a Suprema Corte de Delaware entendeu que a terceira questão apresentada pelo acionista minoritário da Sinven efetivamente constituía self-dealing, de modo que o entire fairness test havia sido corretamente utilizado pela Court of Chancery de Delaware:

Clearly, Sinclair's act of contracting with its dominated subsidiary was selfdealing. Under the contract Sinclair received the products produced by Sinven, and of course the minority shareholders of Sinven were not able to share in the receipt of these products. If the contract was breached, then Sinclair received these products to the detriment of Sinven's minority shareholders. We agree with the Chancellor's finding that the contract was breached by Sinclair, both as to the time of payments and the amounts purchased.

Although a parent need not bind itself by a contract with its dominated subsidiary, Sinclair chose to operate in this manner. As Sinclair has received the benefits of this contract, so must it comply with the contractual duties.

Under the intrinsic fairness standard, Sinclair must prove that its causing Sinven not to enforce the contract was intrinsically fair to the minority shareholders of Sinven. Sinclair has failed to meet this burden. Late payments were clearly breaches for which Sinven should have sought and received adequate damages. As to the quantities purchased, Sinclair argues that it purchased all the products produced by Sinven. This, however, does not satisfy the standard of intrinsic fairness. Sinclair has failed to prove that Sinven could not possibly have produced or someway have obtained the contract minimums. As such, Sinclair must account on this claim.

No referido precedente, a Suprema Corte de Delaware não revelou os 
motivos pelos quais instituiu a necessidade de se verificar, por meio de um "advantage/disadvantage test" "159, a existência ou não de self-dealing para atrair a aplicabilidade do entire fairness. No entanto, para SIEGEL, essa decisão teria decorrido da percepção do tribunal de que a análise de transações à luz do entire fairness test exige muito das cortes norteamericanas, que, ademais, poderiam ser inundadas por demandas de minoritários caso não se criasse um filtro para o uso desse standard of review. ${ }^{160}$ Mas, se, de fato, foram esses motivos da decisão em Sinclair, o tribunal parece tê-los abandonado pouco tempo depois, como se verá a seguir.

\section{II.4.2. Weinberger}

Apesar de ser considerado um marco no que se refere à questão ora apreciada, o uso do precedente firmado em Sinclair como parâmetro para decisões futuras ocorreu de forma errática, havendo casos que simplesmente ignoraram o advantage/disadvantage test, bem como outros que, apesar de mencioná-lo, não o aplicaram de forma completa, muitas vezes omitindo um de seus elementos ${ }^{161}$.

Essa inconsistência deve-se, sobretudo, à decisão tomada pela Suprema Corte de Delaware em 1983, doze anos depois de Sinclair, por ocasião do julgamento de Weinberger, que tratava de ação referente a uma operação de cash-out merger ${ }^{162}$ entre a UOP, Inc. e sua controladora The Signal Companies. Nesse precedente, o mencionado tribunal sequer mencionou o teste criado em Sinclair, decidindo que o entire fairness seria aplicável apenas porque a controladora teria definido os dois lados da operação $^{163}$.

\footnotetext{
${ }^{159}$ O termo é utilizado por SIEGEL. Ob. Cit., p. 29.

${ }^{160}$ SIEGEL, Mary. Ob. Cit., p. 51.

${ }^{161}$ Ibid., pp. 52-53.

${ }^{162}$ Uma cash-out merger ocorre quando os acionistas de uma companhia adquirida recebem dinheiro pelo valor de suas ações, e não ações da companhia adquirente.

163 "The requirement of fairness is unflinching in its demand that where one stands on both sides of a transaction, he has the burden of establishing its entire fairness, sufficient to pass the test of
} 
Entretanto, a corte não revogou expressamente o seu entendimento em Sinclair, contribuindo para o imbróglio o fato de que outros casos julgados após Weinberger terem continuado a aplicar o advantage/disadvantage test, ainda que não necessariamente em sua integralidade ${ }^{164}$. Por isso, posteriormente aos julgamentos de Sinclair e Weinberger pela Suprema Corte de Delaware, a definição sobre qual standard of review deve aplicado numa operação entre controladores e controladas se tornou, no mínimo, imprecisa.

\section{II.4.3. O panorama atual}

Ainda que não se possa afirmar que a questão tenha sido pacificada nos dias atuais, em In Re Crimson Exploration Inc. ${ }^{165}$, julgado em 2014, o Vice Chancellor Parsons, após analisar os precedentes mais recentes sobre o tema, proferiu a seguinte opinião que, ao menos, indica um caminho para se verificar as situações em que o entire fairness se faz cabível:

In sum, triggering entire fairness review requires the controller or control group to engage in a conflicted transaction. That conflicted transaction could involve standing on both sides of the transaction, as when a controller buys out the minority, or receiving different consideration than the other stockholders. In the latter situation, entire fairness is deemed appropriate because the controller is presumed to be competing with the minority stockholders for a larger portion of the total consideration the acquirer is willing to pay. Delaware courts appear to have identified three types of cases where the controller "competes with the common": (1) the controller receives disparate consideration, which the board approves; (2) the controller receives a continuing stake in the surviving entity, whereas the minority is cashed out; and (3) the controller receives a unique benefit, despite nominal pro rata treatment of all stockholders.

A respeito, cabe mencionar que o primeiro grupo de casos em que se

careful scrutiny by the courts". Weinberger v. Uop, Inc, 457 A.2d 701 (Del. 1983).

${ }^{164}$ Desse modo, conclui SIEGEL: "In sum, the vast majority of cases decided after Weinberger ignored the advantage/disadvantage test of Sinclair, regardless of whether the case involved a parent-subsidiary relationship or a controlling-shareholder relationship, and regardless of whether the transaction was a merger, another type of ownership issue, or an enterprise issue. Without ever explicitly overruling Sinclair, Weinberger and its progeny have nevertheless rendered the Sinclair advantage/disadvantage test almost obsolete as an effective advantage/disadvantage test. The few post-Weinberger cases that applied the Sinclair test at the threshold all involved enterprise transactions. Very few of that group have been true to the Sinclair formulation. Most cases that applied Sinclair either diluted the test by eliminating the "detriment" component, or used Sinclair reasoning in the fair dealing analysis, but not as a threshold deter. (...). The law has not accounted for these changes, however, and, one suspects, they were unintentional". SIEGEL, Mary. Ob. Cit., pp. 69-70.

${ }^{165}$ In Re Crimson Exploration Inc., Civil Action No 8541-VCP (Del. Ch. Oct. 24, 2014). 
entende que o controlador "compete" com os demais acionistas comuns envolve operações entre a controlada e uma parte independente nas quais a controladora recebe algum benefício adicional na transação em comparação com os demais acionistas.

Esse benefício não necessariamente precisa consistir em maior pagamento em dinheiro pelo valor das ações do controlador. Em In re John Q. Hammons Hotels Inc. S'holder Litig. ${ }^{166}$, por exemplo, o controlador, no âmbito de uma cash-out merger entre sua controlada e uma parte independente, negociou separadamente com esse terceiro e acabou por receber uma pequena participação acionária na nova companhia, além de prerrogativas em caso de sua liquidação, uma vultosa linha de crédito e inúmeros outros direitos contratuais, enquanto os demais acionistas somente embolsaram o pagamento em dinheiro por suas ações.

Apesar de o acionista controlador não ter fixado os termos da operação, a Court of Chancery de Delaware entendeu que o controlador estaria competindo com os minoritários pelo preço total que o adquirente estaria disposto a pagar, de modo que, diante do uso de mecanismos falhos para garantir a plena equitatividade da negociação da operação, o standard of review aplicável seria o entire fairness.

Por sua vez, no segundo grupo, o adquirente permite que o controlador continue com parte de suas ações após uma cash-out merger, enquanto a mesma oportunidade não é conferida aos minoritários, conforme situação presente em In re LNR Prop. Corp. S'holder Litig. ${ }^{167}$.

No último tipo de casos, por fim, o controlador recebe por suas ações

\footnotetext{
${ }^{166}$ In re John Q. Hammons Hotels Inc. S'holder Litig., 2009 WL 3165613 (Del. Ch. Oct. 2, 2009).

${ }^{167}$ In re LNR Prop. Corp. S'holder Litig, 896 A.2d 169 (Del. Ch. 2005). Como explicado pelo Vice Chancellor Parsons, no referido precedente ocorreu a seguinte situação: “[...] the controlling stockholder negotiated a cash-out merger, which included an arrangement by which the controller, together with other members of senior management, would roll part of their proceeds into a $25 \%$ equity stake in the surviving entity. The board had allowed the controller to negotiate the merger. The allegations that the controller acted as both buyer and seller, and thus was conflicted and may not have sought the highest price, created the potential for entire fairness review and sufficed to avoid dismissal". In Re Crimson Exploration Inc., Civil Action No 8541-VCP (Del. Ch. Oct. 24, 2014).
} 
o mesmo valor que os demais acionistas no âmbito de uma operação entre sua controlada e um terceiro independente, mas, por outro lado, a sua racionalidade encontra-se comprometida em razão de algum problema de liquidez. Essa possibilidade foi teoricamente aventada pelo Chancellor Strine ao opinar no caso In re Synthes, Inc. S'holder Litigation ${ }^{168}$, mas, no caso concreto, concluiu-se que as circunstâncias que ensejariam a aplicação do entire fairness não estavam presentes ${ }^{169}$.

\section{II.5. A proteção dos safe harbor statutes}

Discutiu-se, ao longo de diversos anos nas cortes de Delaware, quais seriam os efeitos para a definição do standard of review da adoção de mecanismos capazes de efetivamente afastar o poder do acionista controlador de fixar ou aprovar os termos de determinada operação em que tenha interesse ${ }^{170}$. Questionava-se, assim, se haveria algum "porto seguro" que poderia ser utilizado pelos controladores para se refugiarem da aplicação do entire fairness test - os chamados "safe harbor statutes".

A questão foi finalmente endereçada em Kahn v. Lynch Communication Systems ${ }^{171}$, em que se decidiu que a negociação da operação por um comitê independente ou a sua aprovação pela maioria dos acionistas minoritários resulta no deslocamento do ônus da prova do controlador para o autor da ação. Concluiu-se, no entanto, que esses mecanismos não têm o condão de alterar o standard of review aplicável,

\footnotetext{
${ }^{168}$ In Re Synthes, Inc. Shareholder Litig., 50 A.3d 1022 (Del. Ch. 2012).

${ }^{169}$ Disse o Chancellor Strine: "It may be that there are very narrow circumstances in which a controlling stockholder's immediate need for liquidity could constitute a disabling conflict of interest irrespective of pro rata treatment. Those circumstances would have to involve a crisis, fire sale where the controller, in order to satisfy an exigent need (such as a margin call or default in a larger investment) agreed to a sale of the corporation without any effort to make logical buyers aware of the chance to sell, give them a chance to do due diligence, and to raise the financing necessary to make a bid that would reflect the genuine fair market value of the corporation. In those circumstances, I suppose it could be said that the controller forced a sale of the entity at below fair market value in order to meet its own idiosyncratic need for immediate cash, and therefore deprived the minority stockholders of the share of value they should have received had the corporation been properly marketed in order to generate a bona fide full value bid, which reflected its actual market value. [...] That sort of uncommon scenario, however, has no application here". In Re Synthes, Inc. Shareholder Litig., 50 A.3d 1022 (Del. Ch. 2012).

${ }^{170}$ HAAS, Steven M. Ob. Cit., p. 2254.

${ }^{171}$ Kahn v. Lynch Communication Systems, 638 A.2d 1110 (Del. 1994).
} 
que continuaria a ser o entire fairness.

No referido precedente, como posteriormente resumido em In $R e$ Pure Resources ${ }^{172}$ :

In colloquial terms, the Supreme Court saw the controlling stockholder as the 800-pound gorilla whose urgent hunger for the rest of the bananas is likely to frighten less powerful primates like putatively independent directors who might well have been hand-picked by the gorilla (and who at the very least owed their seats on the board to his support).

$[\ldots]$

All in all, the Court was convinced that the powers and influence possessed by controlling stockholders were so formidable and daunting to independent directors and minority stockholders that protective devices like special committees and majority of the minority conditions (even when used in combination with the statutory appraisal remedy) were not trustworthy enough to obviate the need for an entire fairness review. The Court did, however, recognize that these safety measures had utility and should be encouraged. Therefore, it held that their deployment could shift the burden of persuasion on the issue of fairness from the controlling stockholders and the target board as proponents of the transaction to shareholder-plaintiffs seeking to invalidate it.

Com efeito, em sua decisão, a Suprema Corte de Delaware sustentou que nas operações entre o acionista controlador e a companhia, mesmo nas hipóteses em que há negociação por conselheiros desinteressados, não se poderia assegurar que os termos definidos de fato seriam aqueles que partes independentes negociariam em uma situação de arms's lenght, de modo que, devido a essa incerteza, deveria ser utilizado o entire fairness como meio de proteger os acionistas minoritários.

O tribunal igualmente entendeu que a aprovação da operação pelos acionistas minoritários também não seria suficiente para assegurar a sua efetiva proteção, na medida em que esses acionistas podem ter se sentido coagidos a votar pela aceitação da transação por receio de posterior retaliação dos acionistas controladores:

Even where no coercion is intended, shareholders voting on a parent subsidiary merger might perceive that their disapproval could risk retaliation of some kind by the controlling stockholder. For example, the controlling stockholder might decide to stop dividend payments or to effect a subsequent cash out merger at a less favorable price, for which the remedy would be time consuming and costly litigation. At the very least, the potential for that perception, and its possible

${ }^{172}$ In Re Pure Resources, 808 A.2d 421 (Del. Ch. 2002). 
impact upon a shareholder vote, could never be fully eliminated ${ }^{173}$.

A decisão tomada em Kahn v. Lynch Communication Systems, no entanto, não respondeu qual seria o standard of review apropriado no caso de uma operação que conte, ao mesmo tempo, com a negociação por um comitê independente e pela aprovação da maioria dos acionistas minoritários. Essa pergunta ficou em aberto por quase vinte anos, tendo sido esclarecida somente em 2013, quando do julgamento do caso In $R e$ MFW Shareholders Litig. ${ }^{174}$ pela Court of Chancery de Delaware.

Em breve síntese, o caso envolvia uma cash-out merger proposta pela MacAndrews \& Forbes, acionista controladora da $\mathrm{M} \quad \& \quad \mathrm{~F}$ Worldwide ("MFW”), em que se ofereceu aos acionistas minoritários da MFW o valor de US\$24 por cada uma de suas ações. No entanto, desde o início da proposta, que resultaria no fechamento de capital da MFW, a MacAndrews \& Forbes afirmou que não prosseguiria com a operação se ela não fosse aprovada por um comitê especial independente e pela maioria dos acionistas minoritários.

Após a sua instalação, o comitê independente se reuniu por oito vezes, contratou seus próprios assessores legais e financeiros, negociou com a MacAndrews \& Forbes o aumento do valor de sua oferta para US\$25 por ação, aprovando, por fim, os termos finais propostos. Em seguida, após receberem as informações relativas ao histórico de negociações da operação, 65\% dos acionistas minoritários da MFW votaram a favor da operação.

Entretanto, um acionista da MFW ingressou com uma ação judicial contra os administradores da companhia e sua acionista controladora, alegando que os termos da transação não teriam sido justos, bem como que os membros do comitê especial não poderiam ser considerados independentes, pois teriam relações econômicas e comerciais com a

\footnotetext{
${ }^{173}$ Kahn v. Lynch Communication Systems, 638 A.2d 1110 (Del. 1994).

${ }^{174}$ In Re MFW Shareholders Litig., 67 A.3d 496 (Del. Ch. 2013).
} 
MacAndrews \& Forbes.

A primeira pergunta a ser respondida, assim, referia-se a qual standard of review deveria ser utilizado no julgamento do caso. De um lado, os acionistas controladores e administradores da MFW defendiam o uso da business judgment rule, enquanto, de outro, o autor da ação alegava, como esperado, que o entire fairness seria o único meio de se aferir a equitatividade da operação, como decidido em Kahn v. Lynch Communication Systems.

Em sua decisão, o então Chancellor Strine argumentou, ainda na primeira linha de seu voto, que o caso representava uma novel questão de direito, porque, após a decisão de Kahn v. Lynch Communication Systems, nenhuma operação submetida à avaliação da Court of Chancery ou da Suprema Corte de Delaware adotou conjuntamente os dois mecanismos indicados naquela decisão como passíveis de realocar o ônus da prova para o autor da ação.

No entendimento do então Chancellor Strine, que no ano seguinte foi alçado ao cargo de Chief Justice da Suprema Corte de Delaware, isso teria ocorrido porque os controladores não possuiriam incentivos para o uso dessa estrutura, uma vez que não sabiam exatamente quais seriam os seus efeitos em uma eventual ação judicial em que os termos da operação fossem questionados:

Uncertainty about the answer to a question that had not been put to our Supreme Court thus left controllers with an incentive system all of us who were adolescents (or are now parents or grandparents of adolescents) can understand. Assume you have a teenager with math and English assignments due Monday morning. If you tell the teenager that she can go to the movies Saturday night if she completes her math or English homework Saturday morning, she is unlikely to do both assignments Saturday morning. She is likely to do only that which is necessary to get to go to the movies - i.e., complete one of the assignments leaving her parents and siblings to endure her stressful last-minute scramble to finish the other Sunday night ${ }^{175}$.

Salientou-se, ademais, que restaria claro que, no caso concreto, o

${ }^{175}$ In Re MFW Shareholders Litig., 67 A.3d 496 (Del. Ch. 2013). Grifos no original. 
comitê especial, caso tivesse sido adotado isoladamente, ensejaria o deslocamento do ônus probatório para o autor da ação, considerando: (i) a concreta independência dos membros desse comitê; (ii) o fato de que se garantiu ao comitê a possibilidade de contratar seus próprios assessores legais e financeiros, o que foi efetivamente realizado; e (iii) que o comitê tinha a possibilidade de negociar os termos da operação (e efetivamente o fez), bem como (e principalmente) o poder de vetar definitivamente a sua aprovação.

Do mesmo modo, não houve qualquer indício de que os acionistas minoritários não foram informados de todos os aspectos relevantes da operação, porque a proxy statement continha todas as informações materiais da transação, incluindo o fato de que o comitê no início buscou alcançar o valor de US\$30 por ação na oferta, o que foi recusado pela MacAndrews \& Forbes. Tampouco foram encontradas evidências de que ocorreu algum tipo de tentativa de coação dos acionistas minoritários por parte da controladora; ao contrário, por diversas vezes ao longo da negociação da operação foi reafirmado que ela somente prosseguiria caso satisfeitas as condicionantes anunciadas.

Diante dessas constatações, o Chancellor concluiu que o uso de uma estrutura como a presente naquele caso resultaria no reestabelecimento da business judgmente rule como o standard of review mais apropriado:

Although rational minds may differ on the subject, the court concludes that when a controlling stockholder merger has, from the time of the controller's first overture, been subject to (i) negotiation and approval by a special committee of independent directors fully empowered to say no, and (ii) approval by an uncoerced, fully informed vote of a majority of the minority investors, the business judgment rule standard of review applies.

This conclusion is consistent with the central tradition of Delaware law, which defers to the informed decisions of impartial directors, especially when those decisions have been approved by the disinterested stockholders on full information and without coercion. Not only that, the adoption of this rule will be of benefit to minority stockholders because it will provide a strong incentive for controlling stockholders to accord minority investors the transactional structure that respected scholars believe will provide them the best protection, a structure where stockholders get the benefits of independent, empowered negotiating agents to bargain for the best price and say no if the agents believe the deal is not advisable for any proper reason, plus the critical ability to determine for 
themselves whether to accept any deal that their negotiating agents recommend to them.

A transactional structure with both these protections is fundamentally different from one with only one protection. A special committee alone ensures only that there is a bargaining agent who can negotiate price and address the collective action problem facing stockholders, but it does not provide stockholders any chance to protect themselves. A majority-of-the-minority vote provides stockholders a chance to vote on a merger proposed by a controller-dominated board, but with no chance to have an independent bargaining agent work on their behalf to negotiate the merger price, and determine whether it is a favorable one that the bargaining agent commends to the minority stockholders for acceptance at a vote. These protections are therefore incomplete and not substitutes, but are complementary and effective in tandem.

O entendimento da Court of Chancery foi posteriormente ratificado pela Suprema Corte de Delaware, em 2014, cabendo transcrever o seguinte excerto dessa decisão, que sintetiza as principais conclusões do referido tribunal:

To summarize our holding, in controller buyouts, the business judgment standard of review will be applied if and only if: (i) the controller conditions the procession of the transaction on the approval of both a Special Committee and a majority of the minority stockholders; (ii) the Special Committee is independent; (iii) the Special Committee is empowered to freely select its own advisors and to say no definitively; (iv) the Special Committee meets its duty of care in negotiating a fair price; (v) the vote of the minority is informed; and (vi) there is no coercion of the minority ${ }^{176}$.

Enfim, no que concerne à análise de operações realizadas entre acionistas controladores e suas controladas, os entendimentos exarados no âmbito do caso envolvendo a MFW implementaram um novo marco jurisprudencial. Após essas decisões, inclusive, não apenas os próprios julgamentos realizados em Delaware passaram a seguir o precedente instituído, mas também algumas decisões do Poder Judiciário de Nova York $^{177}$. E, diante da relevância da jurisprudência de Delaware em assuntos societários, esse movimento tende a se ampliar para outros tribunais americanos.

\footnotetext{
${ }^{176}$ Kahn v. M\&F Worldwide Corp., 88 A.3d 635 (Del. 2014). Grifos no original.

177 Erie Cnty. Emps. Ret. Sys. v. Blitzer (in Re Kenneth Cole Prods., Inc., S'Holder Litig), 52 N.E.3d 214, 280 (N.Y., 2016).
} 


\section{II.5. Análise crítica da evolução jurisprudencial norte- americana}

Como nota FAN, o fair dealing, elemento processual do entire fairness test, incorporou duas outras estratégias de governança ${ }^{178}$. Primeiro, a de trusteeship, presente no forte incentivo ao uso de comitês independentes para negociação dos termos da operação. Segundo, a de veto, ao se estimular a aprovação da operação apenas pelos acionistas minoritários. E, embasando essas duas estratégias, tem-se o full disclosure, representada pelo dever do controlador de divulgar todas as informações materiais sobre a operação que detiver.

Nesse sentido, conclui-se pela experiência norte-americana que a incorporação de outras estratégias indica que a efetiva implementação dos standards enfrenta dificuldades práticas relacionadas ao seu enforcement, especialmente tratando-se de operações complexas como as que, não raro, ocorrem no contexto societário. A melhor opção legislativa para se controlar o eventual oportunismo do acionista controlador, desse modo, aparenta ser a combinação de estratégias de controle ex post com outras de controle ex ante, iluminadas pela sempre necessária presença do full disclosure - e não o uso de um ou outro tipo isoladamente.

Até mesmo em Delaware, afinal, como se observa da evolução de sua jurisprudência até o caso In Re MFW Shareholders Litig. ${ }^{179}$, parece que se chegou à conclusão de que a associação de estratégias regulatórias de governança, que buscam instituir mecanismos para facilitar o poder de influência dos acionistas minoritários nas decisões tomadas pelo controlador, pode ser tão eficiente, no contexto controlador $v$. minoritários, quanto o uso puro de uma estratégia regulatória baseada em standards.

Em verdade, sequer se pode descartar a possibilidade de que uma combinação de estratégias como a utilizada no precedente anteriormente

\footnotetext{
${ }^{178}$ FAN, Chunyan. Ob. Cit., p. 149.

${ }^{179}$ In Re MFW Shareholders Litig., 67 A.3d 496 (Del. Ch. 2013).
} 
mencionado possa ser até mesmo mais eficiente do que os standards. O objetivo principal das estratégias para a redução dos custos de agência é, enfim, melhorar a eficiência econômica da relação de agência, que, não se pode deixar de considerar, também é afetada, em maior ou menor grau, pelos custos regulatórios.

Cumpre registrar, nesse ponto, que, em seu estudo comparativo entre a aplicação de estratégias baseadas em standards nos Estados Unidos, no Reino Unido e na China, FAN conclui que, do ponto de vista do acionista controlador, a motivação para a utilização de uma arm's length bargain, por meio da instituição de comitês independentes para negociar os termos da operação, ou de se abster de votar na deliberação da operação, delegando à maioria dos acionistas minoritários o poder de decisão, é, sobretudo, o de evitar os altos custos de um litígio judicial ${ }^{180}$.

Por conta disso, a autora critica o entendimento que até então prevalecia na jurisprudência norte-americana ${ }^{181}$, esposado em Kahn $v$. Lynch Communication Systems ${ }^{182}$, de que o entire fairness seria o único standard of review aplicável em operações envolvendo os acionistas controladores independentemente dos safe harbors utilizados, porque, ao fim e ao cabo, o excessivo enfoque na revisão judicial dessas transações poderia desencorajar os acionistas controladores a adotarem mecanismos procedimentais (fair dealing), assim podendo prejudicar os próprios acionistas minoritários, notadamente em operações cuja aferição do fair price seja extremamente complexa ${ }^{183}$.

Contudo, com o precedente instituído a partir do julgamento do caso In Re MFW Shareholders Litig. ${ }^{184}$, criaram-se fortes incentivos para

\footnotetext{
${ }^{180}$ FAN, Chunyan. Ob. Cit., p. 120.

${ }^{181}$ Ao que se tem notícia, a tese de doutorado da autora foi finalizada antes da decisão da Court of Chancery sobre o caso envolvendo a MFW, apesar de ter sido defendida somente em 4 de julho de 2013 na Universidade de Groninge, ou seja, após aquele julgamento.

${ }^{182}$ Kahn v. Lynch Communication Systems, 638 A.2d 1110 (Del. 1994).

${ }^{183}$ FAN, Chunyan. Ob. Cit., p. 120.

${ }^{184}$ In Re MFW Shareholders Litig., 67 A.3d 496 (Del. Ch. 2013).
} 
estimular o acionista controlador a estabelecer um processo justo de negociação das operações em que figure como parte interessada, favorecendo-se, em consequência, os próprios minoritários. Desse modo, o desfecho da evolução jurisprudencial, que aparentemente instituía uma situação de regulação excessiva, parece, portanto, ter sido bem concluído. 


\section{CAPÍTULO III. UMA TENTATIVA DE INTERNALIZAÇÃO DO MODELO NORTE-AMERICANO}

Apresentou-se, no capítulo anterior, a forma de aplicação dos standards como estratégia regulatória no direito norte-americano, com enfoque no contexto do latente conflito entre acionistas controladores e minoritários. Com base nisso será possível examinar criticamente a tentativa de internalização do modelo norte-americano pela Comissão de Valores Mobiliários, consubstanciada no Parecer de Orientação CVM nº 35, de 2008 .

\section{III.1. Regras legais}

A Lei $n^{\circ}$ 6.404, de 1976, não se encontra alheia à problemática existente no contexto de incorporação envolvendo companhias controladoras e controladas. Ao contrário, já na própria Exposição de Motivos da Lei $\mathrm{n}^{\circ}$ 6.404, de 1976, salientou-se que tais operações mereceriam normas especiais de proteção aos acionistas minoritários, vez que, nesses casos, inexistem "duas maiorias acionárias distintas, que deliberem separadamente sobre a operação, defendendo os interesses de cada companhia" ${ }^{\prime 185}$.

A solução dada para esse problema pela Lei $\mathrm{n}^{\circ}$ 6.404, de 1976, em seu art. 264, conforme alterado pelas Leis $\mathrm{n}^{\circ} 9.457$ e $\mathrm{n}^{\circ} 10.303$, de 1997 e 2001, respectivamente, foi a necessidade de inclusão na justificação da operação, a qual deve ser apresentada à assembleia geral, de cálculo das relações de substituição das ações dos acionistas não controladores da controlada com base no valor do patrimônio líquido das ações da controladora e da controlada, avaliados os dois patrimônios segundo os mesmos critérios e na mesma data, a preços de mercado, ou com base em outro critério aceito pela CVM, no caso de companhias abertas.

Desse modo, nos termos do $\S 3^{\circ}$ do art. 264 da Lei $n^{\circ}$ 6.404, de 1976,

${ }^{185}$ Exposição de Motivos no 196, de 24 de junho de 1976, do Ministério da Fazenda. 
se as relações de substituição das ações dos acionistas não controladores, previstas no protocolo da incorporação, forem menos vantajosas que as resultantes da comparação prevista no artigo em comento, os acionistas dissidentes da deliberação da assembleia geral da controlada que aprovar a operação, observado o disposto nos arts. 137, II, e 230, do mesmo diploma legal, podem optar entre o valor de reembolso fixado nos termos do art. 45 e o valor do patrimônio líquido a preços de mercado.

Saliente-se, por oportuno, que a Lei $\mathrm{n}^{\mathrm{o}} 11.303$, de 2001 , alterou o $\S^{\circ}$ do art. 264 da Lei $\mathrm{n}^{\circ}$ 6.404, de 1976, de modo que as normas previstas no referido artigo atualmente são aplicáveis não apenas à incorporação de controlada por sua controladora, abrangendo também as seguintes operações de reestruturação societária: (i) incorporação de controladora por sua controlada; (ii) fusão de companhia controladora com a controlada; (iii) incorporação de ações de companhia controlada ou controladora; (iv) incorporação, fusão e incorporação de ações de sociedades sob controle comum.

Como se percebe da sistemática contida no dispositivo legal em comento, a lei societária brasileira adotou uma estratégia regulatória de saída como principal solução para o inerente conflito existente nas operações que envolvem sociedades controladas e controladoras ou sociedades sob controle comum. Aliás, vale ressaltar que, de acordo com o Diretor da CVM Pedro Marcílio, essa modalidade de estratégia regulatória "foi utilizada de modo preferencial na Lei 6.404/76, no seu texto original, e mesmo após as reformas legislativas" ${ }^{\prime 186}$.

Cumpre registrar, nesse ponto, que o art. 264 da Lei $n^{\circ} 6.404$, de 1976, vem sendo reiteradamente interpretado pela doutrina e por precedentes da CVM como um aval implícito ao exercício de voto do acionista controlador nas operações abarcadas pelo referido dispositivo,

\footnotetext{
${ }^{186}$ Processos CVM RJ2006/7204 e RJ2006/7213, Rel. Dir. Pedro Oliva Marcílio de Souza, julg. $17 / 10 / 2006$.
} 
entendendo-se igualmente que a relação de troca pode ser livremente negociada pelas companhias ${ }^{187}$.

Ocorre, porém, que "nenhum desses antecedentes significa, nem poderia significar", como afirmado pelo Diretor Marcos Pinto, "que o art. 264 da Lei $n^{\circ}$ 6.404/76 exclui outros mecanismos legais de proteção aos acionistas minoritários" ${ }^{\prime 188}$. Com efeito, ao lado do direito de recesso pelo valor do patrimônio líquido a preços de mercado, quando cabível, a Lei $\mathrm{n}^{\mathrm{o}}$ 6.404, de 1976, adota diversas outras estratégias no cenário em questão, interessando-nos, sobretudo, para fins do presente trabalho, a exigência de que as operações entre acionista controlador e companhia observem condições estritamente comutativas.

A fim de garantir essa exigência de equidade, a lei societária impõe deveres e responsabilidades distintos, porém complementares, aos administradores e aos acionistas controladores, conforme exposto em voto proferido pelo Diretor Pablo Renteria:

14. Neste tocante, o que se verifica é que a Lei $n^{\circ}$ 6.404/1976 submeteu administradores e controladores a responsabilidades distintas no que diz respeito à realização de operações entre a companhia e sociedades integrantes do mesmo grupo econômico.

15. De uma parte, em atenção ao disposto no art. 245, cumpre aos administradores zelar para que essas transações sejam equitativas. Ou seja, devem agir com especial diligência, adotando, durante o processo decisório, medidas aptas a resguardar os interesses da companhia frente ao risco de favorecimento do controlador.

16. Este Colegiado já esclareceu, a propósito, que "as operações entre controlador e controlada colocam um ônus muito maior sobre os administradores envolvidos, (...). Todo o cuidado e diligência que se exige dos administradores em condições normais deve ser redobrado em negócios entre partes relacionadas (...)".

17. Dada a natureza eminentemente procedimental desse dever, a conduta dos administradores se presta perfeitamente ao tipo de escrutínio levado a cabo pela SEP nos autos deste processo, que, como visto, centra-se no modo de condução da negociação que antecedeu à contratação. Incumbe então à CVM avaliar as medidas adotadas pelos administradores para assegurar o equilíbrio da operação, tendo em conta as circunstâncias do caso concreto - em especial a relevância do

187 JACOMIMI, Fernanda Perez et al. Incorporação de Sociedades e Incorporação de Ações: Operações de Reorganização Societária entre Controladora e Controlada e os Pareceres de Orientação CVM 34 e 35. Revista de Direito Empresarial (RT Online), Vol. 1, nov. 2013, p. 5.

188 Disponível em <http://www.cvm.gov.br/export/sites/cvm/decisoes/anexos/0004/5995-0.pdf>. Acesso em 21 de maio de 2017. 
negócio para a companhia e o tempo de que dispunham os administradores para tomar a decisão.

18. De outra parte, em consonância com o disposto no art. $117, \S 1^{\circ}$, alínea "f", o controlador não pode abusar de sua autoridade sobre a administração para contratar com a companhia em condições não equitativas. Extrai-se do texto normativo que a análise da CVM, neste caso, há de ser substancial, configurandose o abuso apenas mediante a demonstração de que a transação foi lesiva para a companhia. Ainda que o processo de negociação que levou à contratação não tenha sido conduzido a contento, o controlador deve ser responsabilizado apenas se restar comprovado que os termos do contrato o favoreceram em detrimento da companhia ${ }^{189}$.

Portanto, assim como ocorre no direito norte-americano, também se exige, no direito brasileiro, que as operações entre sociedades relacionadas sejam inteiramente equitativas, o que essencialmente significa dizer que o legislador pátrio igualmente adotou uma estratégia regulatória baseada em standards no que concerne à análise dessas operações. E isso resulta, como explorado nos capítulos anteriores, em grandes dificuldades na determinação a posteriori da consonância ou não dessas operações aos ditames legais, mormente porque, não raro, estão cercadas por grande complexidade.

Em decorrência dessa constatação, a Comissão de Valores Mobiliários vem expressando diversas opiniões, por meio de pareceres de orientação $^{190}$, que, ao fim e ao cabo, objetivam atenuar as complexidades inerentes à adoção de uma estratégia regulatória baseada em standards, como feito pela Lei $n^{\circ} 6.404$, de 1976, no que tange às operações abarcadas pelo art. 264 desse diploma legal. Como se poderá perceber, a CVM, ciente das dificuldades concernentes à aferição da comutatividade de operações de reestruturação societária, tem buscado, por meio de interpretações, conferir aos próprios acionistas atingidos por essas operações a possibilidade de interferir no processo decisório.

Esse movimento do órgão regulador encontrou seu auge com a

\footnotetext{
${ }^{189}$ PAS CVM no RJ2012/11199, Rel. Dir. Pablo W. Renteria, julg. 22/03/2016.

${ }^{190}$ De acordo com a Deliberação CVM no 01 , de 1978, os pareceres de orientação são os expedientes "através dos quais a CVM, nos termos do disposto no artigo 13 da LEI 6.385/1976, dará orientação aos agentes do mercado e aos investidores sobre matéria que cabe à CVM regular. Os Pareceres de Orientação servirão, também, para veicular as opiniões da CVM sobre interpretação das Leis os 6.385/76 e 6.404/76 no interesse do mercado de capitais".
} 
edição do Parecer de Orientação CVM n ${ }^{\circ} 35$, de 2008, o qual pode ser considerado como uma verdadeira tentativa da CVM de internalizar o modelo norte-americano ao direito pátrio. Antes de tratar desse parecer, porém, cumpre explorar o conteúdo do Parecer de Orientação CVM no 34, de 2006, que consistiu no primeiro grande passo dado pela CVM para atenuar a conflituosa situação que permeia as operações de reestruturação societária entre sociedades controladas e controladoras.

\section{III.2. Parecer de Orientação CVM no 34, de 2006}

\section{III.2.1. Contextualização}

Com a criação dos segmentos especiais de listagem pela Brasil Bolsa Balcão - B3, nos anos 2000, diversas companhias abertas passaram a realizar operações com o objetivo de viabilizar sua migração para os referidos segmentos diferenciados de listagem, o que muitas vezes requeria a unificação das espécies de ações de emissão da companhia ${ }^{191}$.

No entendimento da CVM, consubstanciado no Parecer de Orientação CVM nº 34, de 2006, o movimento de migração das companhias para os segmentos especiais de listagem seria salutar, não cabendo à autarquia, assim, criar empecilhos para a sua realização. No entanto, para o órgão regulador, as estruturas societárias adotadas para a viabilização dessa migração, além da conformidade aos ditames legais, também deveriam assegurar a participação dos acionistas não controladores no processo decisório,

especialmente quando importarem em tratamento diferenciado entre acionistas titulares de ações de mesma espécie e classe, ou tomarem por base avaliações que considerem não apenas os direitos econômicos ou políticos atribuídos às ações, mas também suposições de sobrevalorização de ações detidas por certos acionistas não comprovadas por efetivas negociações entre partes independentes ${ }^{192}$.

\footnotetext{
${ }^{191}$ Como se sabe, o regulamento do Novo Mercado da Brasil Bolsa Balcão - B3 exige que o capital social das companhias listadas nesse segmento diferenciado de governança corporativa seja formado exclusivamente por ações ordinárias.

${ }^{192}$ Parecer de Orientação CVM n ${ }^{\circ}$ 34, de 2006.
} 
A Comissão de Valores Mobiliários, contudo, identificou que muitas dessas operações estariam sendo arquitetadas de modo a atribuir, com base em laudo de avaliação, uma relação de troca distinta (e mais favorável) às ações de emissão da companhia detidas pela sociedade controladora, ainda que o único ativo (ou único ativo relevante) desta fossem as próprias ações de emissão da companhia.

Essa situação caracterizaria, na visão da CVM, um benefício particular aos detentores de ações com relação de troca mais benéfica, o que impediria o exercício do direito de voto por tais sócios na deliberação sobre a operação, em função do disposto no art. $115, \S 1^{\circ}$, da Lei $n^{\circ} 6.404$, de 1976. Por isso, o órgão regulador entendeu por bem explicitar sua opinião por meio de um parecer de orientação, a fim de conferir uma ampla disseminação de seu entendimento aos agentes de mercado.

\section{III.2.2. Conteúdo}

O Parecer de Orientação CVM n ${ }^{\circ}$ 34, de 2006, indica quatro situações em que, na visão da CVM, haveria impedimento de voto dos sócios detentores das ações que seriam favorecidas na relação de troca proposta em operações estruturadas com o fim de viabilizar sua migração para segmentos especiais de listagem da bolsa de valores.

Tais situações, em regra, envolvem operações de incorporação, direta ou reversa, da própria companhia ou de suas ações, na holding, assim definida a sociedade controladora que possui como único ativo (ou único ativo relevante) as ações do acionista controlador da companhia ou do proponente da operação.

A primeira hipótese ocorre caso a proposta de incorporação considere uma relação de troca que atribua valor diferente às ações de emissão da companhia que sejam de propriedade da holding comparativamente às ações de mesma espécie e classe detidas pelos demais acionistas.

A segunda se apresenta quando a proposta de incorporação considera 
uma relação de troca que atribua valor distinto às ações de emissão da companhia que sejam de propriedade da holding e às demais ações, ainda que de espécie ou classe diversas, mas desde que essa diferença não se baseie em laudo de valor econômico que sustente essa distinção com base em critérios objetivamente verificáveis.

A terceira situação mencionada no Parecer de Orientação CVM n ${ }^{\circ}$ 34, de 2006, é aquela em que a operação ao final confira o mesmo número de ações da holding a todas as espécies e classes de ações de emissão da companhia, mas o número de ações emitidas pela holding antes da operação era proporcionalmente superior ao número de ações da companhia.

O entendimento esposado pela CVM é o de que, nesses três casos anteriormente descritos, a holding e os acionistas que nela possuem participação direta, por força do disposto no art. $115, \S 1^{\circ}$, da Lei $\mathrm{n}^{\circ} 6.404$, de 1976, estão impedidos de votar na deliberação da operação.

Na quarta e última hipótese mencionada pela CVM, por fim, a proposta de incorporação contempla diferentes relações de troca considerando as diferentes espécies de ações detidas pelos acionistas que não possuam participação societária na holding. Nesse caso, para a CVM, os sócios detentores das ações com a relação de troca mais benéfica estão impedidos de votar, desde que a distinção nas relações de troca não esteja baseada em critérios objetivamente verificáveis ${ }^{193}$.

\section{III.2.3. A estratégia adotada pela CVM}

No Parecer de Orientação CVM no 34, de 2006, conforme anteriormente demonstrado, a CVM entendeu que operações com relações de trocas mais favoráveis à sociedade controladora impediriam o exercício de seu voto, na medida em que, para a autarquia, essa situação caracterizaria hipótese de benefício particular, atraindo a incidência do

\footnotetext{
193 O fundamento legal utilizado pelo órgão regulador, na hipótese em comento, também é o art. $115, \S 1^{\circ}$, da Lei $n^{\circ} 6.404$, de 1976 , novamente porque, no entendimento da autarquia, encontra-se presente a situação de benefício particular.
} 
comando do art. $115, \S 1^{\circ}$, da Lei $n^{\circ} 6.404 / 76$. Ou seja, por meio do parecer em questão, a CVM, na prática, buscou conferir aos acionistas minoritários afetados o poder de vetar a operação.

Com isso, a Comissão de Valores Mobiliários alterou o enfoque regulatório sobre a matéria. Antes, pela lei societária, combinava-se uma estratégia regulatória de associação de saída (o direito de recesso) com outra estratégia regulatória de controle baseada em standards (a exigência de comutatividade da operação). Após a interpretação externada pelo órgão regulador por meio do Parecer de Orientação CVM no 34, de 2006, passouse a conjugar a mesma estratégia regulatória de associação de saída (o direito de recesso) com uma estratégia de governança de decisão (o veto conferido aos minoritários).

Saliente-se, por oportuno, que a CVM já havia sido chamada a se manifestar sobre reestruturações societárias semelhantes àquelas que foram posteriormente objeto do parecer de orientação em questão, tendo decidido, ao menos em uma oportunidade, pela ilegalidade da operação ${ }^{194}$. Nesse precedente, que envolvia uma reestruturação societária dividida em três etapas (aquisição do controle acionário, oferta pública prevista no art. 254A da Lei $n^{\circ}$ 6.404, de 1976, e incorporação de ações, respectivamente), o Colegiado da CVM entendeu que a proposta de incorporação contrariava a legislação vigente, porque não assegurava tratamento equitativo a todos os acionistas.

Em voto proferido no âmbito dos Processos CVM RJ2006/7204 e RJ2006/7213 ${ }^{195}$, o Diretor Pedro Marcílio explicitou os motivos pelos quais a CVM alterou seu entendimento de uma estratégia de proibição, adotada no citado precedente, para uma estratégia que definiu como sendo de "legitimação do processo decisório", abraçada no âmbito do Parecer de Orientação CVM nº 34, de 2006:

\footnotetext{
${ }^{194}$ Processo CVM RJ2003/12770, julg. 26/12/2013.

195 Processos CVM RJ2006/7204 e RJ2006/7213, Rel. Dir. Pedro Oliva Marcílio de Souza, julg. $17 / 10 / 2006$.
} 
25. [...] percebe-se, claramente, que a estratégia preferida pela CVM para atuar sobre reestruturações societárias consideradas iníquas, até antes do Parecer de Orientação 34/06, é a de proibição. A análise desses casos, no entanto, tem mostrado a ineficácia dessa estratégia [...].

26. Diante de uma tal experiência, é de se questionar se não seria mais benéfico aos acionistas não controladores o estabelecimento de um procedimento legitimador das operações que vieram a ser proibidas, de modo a permitir que acionista controlador e acionistas não controladores (ou seus representantes) estabelecessem termos adequados para a assunção da dívida ou a aquisição do ativo fiscal ou mesmo discutissem um relação de substituição adequada, ao invés de, simplesmente, proibir-se as operações.

$[\ldots]$

35. A estratégia regulatória adotada no Parecer de Orientação 34/06 é a de legitimação, em seu estado puro. Entendeu a CVM não ser a melhor opção impedir a realização de uma operação que pode ser benéfica para a Companhia e, também, para todos os seus acionistas, a depender de seus termos.

36. O desenvolvimento recente do mercado acionário brasileiro, o melhor aparelhamento dos investidores institucionais, o desenvolvimento da mídia financeira e empresarial, o reforço dos departamentos de análise dos bancos de investimento e das corretoras e o aumento da efetividade da atuação da CVM permitem a migração da estratégia de proibição para a estratégia de legitimação, em casos como o enfrentado pelo Parecer de Orientação 34/06, com ganhos para o sistema.

\section{III.3. Parecer de Orientação CVM no 35, de 2008}

\section{III.3.1. Contextualização}

Em maio de 2008, o então Diretor Marcos Barbosa Pinto propôs ao Colegiado da CVM, por meio de memorando de sua autoria ${ }^{196}$, a edição de um parecer de orientação com o fim de detalhar os deveres fiduciários dos administradores no processo de negociação de fusões, incorporações e incorporações de ações envolvendo sociedade controladora e suas controladas ou sociedades sob controle comum ${ }^{197}$.

De acordo com o referido Diretor, das operações frequentes no mercado de capitais brasileiro, as incorporações de controladas por suas controladoras seriam as mais problemáticas, porque:

a) poderiam causar prejuízos significativos aos acionistas minoritários, na hipótese de desequilíbrio na relação de troca das ações;

\footnotetext{
${ }^{196}$ Disponível em <http://www.cvm.gov.br/export/sites/cvm/decisoes/anexos/0004/5995-0.pdf〉. Acesso em 21 de maio de 2017.

${ }^{197}$ Isto é, aquelas operações que estão submetidas ao art. 264 da Lei no ${ }^{\circ}$ 6.404, de 1976.
} 
b) são coercitivas aos acionistas minoritários, posto que podem ser aprovadas pela maioria dos acionistas, inclusive pelo controlador nos casos em que figure como contraparte da operação;

c) o direito de recesso não seria suficiente para tutelar os interesses dos acionistas minoritários em caso do abuso do poder de controle, por (i) não ser cabível quando as ações possuem liquidez, (ii) haver a possibilidade de sua fixação pelo valor patrimonial, (iii) pelo fato de o reembolso pelo valor do patrimônio líquido a preços de mercado não refletir, via de regra, o valor justo das ações de uma companhia operacional e, ainda, porque, (iv) no caso do uso do valor econômico para a fixação do valor do reembolso, o avaliador é escolhido em assembleia da qual participa o controlador;

d) o mercado, isoladamente, não conseguiria reprimir eventuais abusos nessas operações, na medida em que os benefícios obtidos poderiam compensar o prejuízo reputacional sofrido pelos controladores; e

e) a CVM e o Poder Judiciário enfrentariam dificuldades na avaliação das relações de troca propostas, considerando que se trata, ao menos parcialmente, de análise subjetiva.

Diante desse contexto, o Diretor Marcos Pinto salientou que esse mesmo cenário estivera presente décadas antes nos Estados Unidos da América, pois se permitia que o controlador exercesse seu direito de voto nas incorporações de controlada, entendendo-se, ademais, que o direito de recesso seria a única alternativa disponível para os minoritários dissidentes, apesar de sua inadequação. Essa situação teria mudado a partir do julgamento do caso Singer v. Magnavox Co. ${ }^{198}$ pela Suprema Corte de Delaware, no qual se decidiu, de acordo com o Diretor Marcos Pinto, que a previsão legal do direito de recesso não afastava os deveres fiduciários dos administradores nas incorporações de controladas. Em sua decisão, a corte deixou claro que os administradores têm o dever de negociar termos e condições de

${ }^{198}$ Singer v. Magnavox Co, 380 A.2d 969 (Del. 1977). 
incorporação que sejam entirely fair para os acionistas minoritários.

Afirmou-se, ademais, que em Weinberger e em casos posteriores a Suprema Corte de Delaware teria focado sua análise no processo de negociação da operação, e não nos seus termos propriamente ditos, posto que um real processo de barganha constituiria a melhor garantia de que o preço negociado teria sido fixado de forma justa. No entendimento do Diretor Marcos Pinto, esse seria o caminho mais adequado, pelos seguintes motivos:

Essa solução processual me parece bastante equilibrada, pois permite a realização de operações vantajosas para a companhia desde que um processo de barganha independente seja realizado.

Essa solução reconhece, claramente, o caráter problemático das incorporações de controladas. Ela não ignora, porém, as dificuldades do Judiciário para avaliar a comutatividade das relações de troca.

Por isso, ela trilha um caminho intermediário. Ela deixa a fixação da relação de troca nas mãos dos que estão em melhor posição para negociar a operação: os administradores, agora sujeitos a regras procedimentais claras que tendem a propiciar negociações independentes.

A minuta de parecer de orientação contida no memorando subscrito pelo Diretor Marcos Pinto, declaradamente idealizada com base na experiência norte-americana, foi submetida à audiência pública ${ }^{199}$, e seu texto final foi aprovado pelo Colegiado da CVM em reunião ocorrida em 26/08/2008. O Parecer de Orientação CVM n ${ }^{\circ}$ 35, originado dessa decisão, foi publicado em 01/09/2008.

\section{III.3.2. Conteúdo}

De acordo com o Parecer de Orientação CVM n ${ }^{\circ}$ 35, de 2008, o entendimento da CVM, no que tange às operações enquadradas no art. 264 da Lei $n^{\circ}$ 6.404/76, é de que compete aos administradores das companhias abertas a instituição de procedimentos e a adoção das medidas necessárias para assegurar que a relação de troca e demais condições dessas operações sejam negociadas de maneira independente ${ }^{200}$, posto que isso tenderia a

${ }^{199}$ Audiência Pública SDM nº 02, de 2008.

200 O Parecer de Orientação CVM n ${ }^{\circ} 35$, de 2008, elenca diversos procedimentos que, no entendimento da CVM, deveriam ser adotados pelos administradores das companhias abertas 
propiciar a sua comutatividade.

Nessa linha, "seguindo a experiência internacional acerca da interpretação dos deveres fiduciários dos administradores" ${ }^{\text {201 }}$, a Comissão de Valores Mobiliários recomendou, por meio do Parecer de Orientação $\mathrm{CVM} \mathrm{n}^{\circ} 35$, de 2008, com relação às operações societárias enquadradas no art. 264 da Lei $n^{\circ}$ 6.404, de 1976, (i) que um comitê especial independente seja constituído para negociar a operação e submeter suas recomendações ao conselho de administração; ou, alternativamente, (ii) que a operação seja condicionada à aprovação da maioria dos acionistas não-controladores, inclusive os titulares de ações sem direito a voto ou com voto restrito.

A CVM sugeriu, ainda, que na formação do comitê especial independente seja adotada uma das seguintes alternativas: (i) comitê composto exclusivamente por administradores da companhia, em sua maioria independentes; (ii) comitê composto por não-administradores da companhia, todos independentes e com notória capacidade técnica, desde que o comitê esteja previsto no estatuto, para os fins do art. 160 da Lei ${ }^{\circ}$ 6.404, de 1976; ou (iii) comitê composto por um administrador escolhido pela maioria do conselho de administração, um conselheiro eleito pelos acionistas não-controladores, e um terceiro, administrador ou não, escolhido em conjunto pelos outros dois membros ${ }^{202}$.

Embora entendesse que a adoção dos referidos procedimentos seriam capazes de indicar que os administradores das companhias abertas

controladas ou, no caso de companhias sob controle comum, de ambas as companhias. A título de exemplo, cumpre citar, dentre outros, os seguintes procedimentos: (i) a relação de troca e demais termos e condições da operação devem ser objeto de negociações efetivas entre as partes na operação; (ii) os administradores devem buscar negociar a melhor relação de troca e os melhores termos e condições possíveis para os acionistas da companhia; (iii) os administradores devem obter todas as informações necessárias para desempenhar sua função; (iv) os administradores devem considerar a necessidade ou conveniência de contratar assessores jurídicos e financeiros; e (v) os administradores devem rejeitar a operação caso a relação de troca e os demais termos e condições propostos sejam insatisfatórios.

${ }^{201}$ Parecer de Orientação CVM no 35, de 2008.

202 Segundo a CVM, a avaliação acerca da independência dos membros do comitê especial independente não pode ser aferida previamente. No entanto, haveria presunção relativa de independência daqueles administradores que se enquadrem na definição de "conselheiro independente" prevista no Regulamento do Novo Mercado da BM\&FBOVESPA. 
envolvidas efetivamente cumpriram com seus deveres fiduciários, a CVM expressamente ressalvou, no próprio Parecer de Orientação CVM nº 35, de 2008, que eles não são exclusivos nem exaustivos, sendo assim possível que os administradores empreguem outros meios a fim de demonstrar a satisfação de seus deveres.

\section{III.3.3. A estratégia adotada pela CVM}

Conforme anteriormente explicitado com relação ao Parecer de Orientação CVM n ${ }^{\circ}$ 35, de 2008, a Comissão de Valores Mobiliários recomenda, em resumo, que as operações de reestruturação societária abrangidas pelo art. 264 da Lei $n^{\circ}$ 6.404, de 1976, sejam negociadas por um comitê especial independente, ou, então, que sejam submetidas à aprovação da maioria dos acionistas não-controladores.

Mais uma vez, portanto, o órgão regulador modificou o foco do tratamento regulatório sobre a matéria, substituindo a combinação de uma estratégia regulatória de associação de saída (o direito de recesso) com outra estratégia regulatória de controle baseada em standards (a exigência de comutatividade da operação), presente originariamente na lei societária, por uma conjugação da mesma estratégia regulatória de associação de saída com estratégias de governança de trusteeship (o incentivo ao uso de comitês independentes) ou de decisão (o veto conferido aos acionistas não controladores), adotadas no Parecer de Orientação CVM nº 35, de 2008.

Não é difícil enxergar, assim, que a CVM nitidamente buscou emular, no direito pátrio, aquilo que há anos vem sendo praticado pela jurisprudência norte-americana, ao menos no que concerne ao elemento procedimental do entire fairness test, que exige, como explicitado no capítulo anterior deste trabalho, a presença de uma negociação arm's length. 


\section{CONCLUSÃO}

Em países em que há forte concentração acionária, como no Brasil, o principal conflito de agência no âmbito das companhias consiste naquele existente entre os acionistas controladores e não-controladores. Esse conflito pode surgir em diversas situações, dentre elas a estudada neste trabalho: operações de reestruturação societária. Como demonstrado no Capítulo I, diversas estratégias são empregadas com o fim de reduzir os custos de agência decorrentes nesse cenário, destacando-se, nas mais diversas jurisdições, o uso de standards.

A partir do estudo de múltiplos precedentes julgados no estado americano de Delaware, realizado no Capítulo II, comprova-se que, tal como já afirmado por KRAAKMAN et $a l^{203}$, GILSON \& GORDON ${ }^{204}$, ALLEN $e t a l^{205}$, entre outros, o uso de standards para a análise de operações entre o acionista controlador e a companhia consiste, ao menos historicamente, na principal estratégia utilizada nos Estados Unidos no contexto do conflito de agência entre o controlador e os acionistas minoritários.

Questiona-se, assim, se esse modelo norte-americano de aplicação de standards poderia ser incorporado ao direito pátrio, como claramente tentou a CVM ao editar o Parecer de Orientação CVM no 35, de 2008, conforme exposto no Capítulo III. A resposta, contudo, é negativa. Com efeito, é forçoso concluir que, embora louvável, a tentativa de internalização do modelo norte-americano ao direito brasileiro pela CVM não pode se aperfeiçoar em razão de significativas diferenças entre os sistemas jurídicos dos dois países.

Como órgão integrante da Administração Pública Indireta, não compete à CVM determinar a indenização dos acionistas minoritários na

\footnotetext{
${ }^{203}$ KRAAKMAN, Reinier et al. Ob. Cit., p. 178.

${ }^{204}$ GILSON, Ronald. J; SCHWARTZ, Alan. Ob. Cit., p. 165.

${ }^{205}$ ALLEN, William T. et al. Ob. Cit., p. 225.
} 
hipótese de prejuízos eventualmente causados por operações de reestruturação societária de interesse do acionista controlador que não possuam condições estritamente comutativas; a autarquia, afinal, não integra o Poder Judiciário.

Desse modo, o mandato da CVM, nesse contexto, limita-se à imposição de penalidades na hipótese de descumprimento dos ditames da Lei $n^{\circ}$ 6.404, de 1976, pelo que o viés de sua atuação é de natureza sancionatória. Isso, por certo, em razão do princípio da presunção de inocência, insculpido no art. $5^{\circ}$, inciso LVII, da Constituição Federal, impede que haja a inversão do ônus probatório, instrumento essencial no modelo norte-americano.

Como visto, no direito norte-americano, nos casos de aplicação do entire fairness test, cumpre ao próprio réu da ação civil demonstrar a plena equitatividade da operação. Para tanto, no contexto de reorganizações societárias que envolvem controladoras e controladas, as cortes judiciais dos Estados Unidos, em especial do estado de Delaware, submetem a operação a uma análise extremamente rigorosa, pairando sempre presente a possibilidade de que os controladores não consigam satisfazer esse dever.

Diante desse cenário, ao longo do tempo, os próprios controladores buscaram, seguindo as opiniões in dicta dos integrantes das cortes americanas, criar mecanismos com o fim de minimizar os riscos de que fossem posteriormente condenados a indenizar os acionistas minoritários por um entendimento do Poder Judiciário.

Os controladores, assim, passaram a não mais votar nas deliberações que possuíam interesse ou então passaram a submeter a operação à aprovação de comitês independentes. O incentivo econômico para essa atitude era certamente o objetivo de obter o relevante efeito, no direito estrangeiro, de devolver o ônus probatório ao autor da ação.

Mais recentemente, como visto, os controladores chegaram ao ponto de utilizar esses dois instrumentos de legitimação conjuntamente, vez que 
essa foi a única estrutura reconhecida pelo Poder Judiciário norte-americano como suficientemente capaz de conferir uma efetiva proteção aos acionistas minoritários, sendo certo que os controladores são incentivados a adotar essa estrutura porque recebem em contrapartida a aplicabilidade da business judgment rule, regra que os protege de eventual responsabilização judicial.

No entanto, diferentemente do que ocorre no direito norteamericano, a CVM, na qualidade de órgão regulador do mercado de capitais, não possui competência legal ou constitucional para, por meio de interpretação, exigir que os próprios acionistas controladores demonstrem $a$ priori que a operação de reestruturação societária por eles deliberada atende aos critérios de equitatividade exigidos pela lei societária, cabendo tãosomente à própria CVM, caso queira responsabilizar o acionista controlador, demonstrar a iniquidade da operação, por meio de um processo administrativo sancionador.

Conclui-se, portanto, que a internalização do modelo norteamericano de aplicação de standards não pode ser realizada pelo regulador brasileiro, ao menos não com base no arcabouço jurídico existente, ante a impossibilidade, decorrente das diferenças existentes entre os sistemas jurídicos dos dois países, de importação de um de seus requisitos essenciais, qual seja, a inversão do ônus da prova. 


\section{BIBLIOGRAFIA}

ALLEN, Willian T. et al. Commentaries and Cases on The Law of Business Organization. $3^{\mathrm{a}}$ edição. Nova York: Aspen Publishers, 2009, 768p.

BAINBRIDGE, Stephen M. The Business Judgment Rule as Abstention Doctrine. Disponível em <http://ssrn.com/abstract=429260>. Acesso em 30 de abril de 2017.

BERLE, Adolf. A.; MEANS, Gardiner C. A Moderna Sociedade Anônima e a Propriedade Privada. São Paulo: Nova Cultural, 1987, 335p.

BLACK, Bernard S. Legal and Institutional Preconditions for Strong Securities Markets. UCLA Law Review, v. 48, 2001, pp. 781-855.

CANTIDIANO, Luiz Leonardo. Análise Crítica do Parecer de Orientação CVM 34. Revista de Direito Bancário e do Mercado de Capitais (RT Online), Vol. 41, julho/setembro de 2008, pp. 133-147.

CARRINGTON, Richard W. The Status of Stockholders Relative to the Internal Affairs of Corporations. Virginia Law Review, v. 5, n. 1, 1917, pp. 43-53.

CHOI, Albert H. Costs and Benefits of Concentrated Ownership and Control. Disponível em <https://papers.ssrn.com/sol3/papers.cfm?abstract _id=2619462>. Acesso em 27 de abril de 2017.

COASE, Ronald. The Nature of the Firm. Economica, New Series, Vol. 4, n. 16, Nov., 1937, pp. 386-405.

COHEN, Zipora. Fiduciary Duties of Controlling Shareholders: A Comparative View. University of Pennsylvania Journal of International Law, v. 12, 1991, pp. 379-410.

DALLEY, Paula J. The Misguided Doctrine of Stockholder Fiduciary Duty. Hostra Law Review, v. 33, ed. 1, 2004, pp. 175-222.

DAMMANN, Jens. The Controlling Shareholder's General Duty of Care: 
A dogma That Should Be Abandoned. University of Illinoius Law Review, n. 2, 2015, pp. 479-506.

DYCK, Alexander; ZINGALES, Luigi. Private Benefits of Control: An International Comparison. The Journal of Finance, v. LIX, n. 2, abril de 2004, pp. 537-600.

EASTERBROOK; Frank H.; FISCHEL, Daniel R. The Economic Structure of Corporate Law. Cambridge: Harvard University Press, 1996, 384p.

EISENBERG, Melvin Aron. The Divergence of Standards of Conduct and Standards of Review in Corporate Law. Fordham Law Review, v. 62, 1993, PP. 437-468.

EIZIRIK, Nelson Laks. O Mito do "Controle Gerencial”: Alguns Dados Empíricos. Revista de Direito Mercantil Industrial, Econômico e Financeiro, São Paulo, ano XXVI, n. 66, abril-junho, 1987, pp. 103.106.

FAN, Chunyan. Bringing Controlling Shareholders to Court: StandardBased Strategies and Controlling Shareholder Opportunism. A Haia: Eleven International Publishing, 2013, 272p.

GILSON, Ronald J.; GORDON, Jeffrey N. Controlling Controlling Shareholders. Disponível em <http://papers.ssrn.com/abstract=417181>. Acesso em 27 de abril de 2017.

GILSON, Ronald. J; SCHWARTZ, Alan. Constraints on Private Benefits of Control: Ex Ante Control Mechanisms versus Ex Post Transaction Review. Journal of Institutional and Theoretical Economics, v. 169, ed. 1, 2013, pp. 160-183.

HAAS, Steven M. Toward a Controlling Shareholder Safe Harbor. Virginia Law Review, V. 90, N. 8, pp. 2245-2304.

JACOBS, Jack B. Fifty Years of Corporate Law Evolution: A Delaware Judge Retrospective. Harvard Business Law Review, V. 5, Ed. 2, 2015, pp. $141-172$ 
JACOMIMI, Fernanda Perez et al. Incorporação de Sociedades e Incorporação de Ações: Operações de Reorganização Societária entre Controladora e Controlada e os Pareceres de Orientação CVM 34 e 35. Revista de Direito Empresarial, Vol. 1, nov. 2013, pp. 173-195.

JENSEN, Michael C.; MECKLING, William H. Theory of the Firm: Managerial Behavior, Agency Costs and Ownership Structure. Disponível em <http://papers.ssrn.com/abstract=94043>. Acesso em 19 de março de 2017.

KRAAKMAN, Reinier et al. The Anatomy of Corporate Law: A Comparative and Functional Approach. $2^{\mathrm{a}}$ edição. Oxford: Oxford University Press, 2009, 322p.

LA PORTA, Rafael et al. Corporate Ownership Around the World. Disponível em <http://www.nber.org/papers/w6625>. Acesso em 27 de abril de 2016.

LAMY FILHO, Alfredo; BULHÕES PEDREIRA, José Luiz. Introdução. In: Direito das Companhias (2 volumes). Coord.: LAMY FILHO, Alfredo; PEDREIRA, José Luiz Bulhões. Rio de Janeiro: Forense, 2009, 2330p.

MACINTOSH, Jeffrey G. et al. The Puzzle of Shareholder Fiduciary Duties. Canadian Business Law Journal, V. 19, 1991, pp. 86-137.

RUDER, David S. Duty of Loyalty: A Law Professor's Status Report. The Business Lawyer, Vol. 40, N. 4, 1985, pp. 1383-1402.

SCHLAG, Pierre J. Rules and Standards. Disponível em https://lawweb.colorado.edu/profiles/pubpdfs/schlag/schlagUCLALR.pdf. Acesso em 26 de abril de 2017.

SIEGEL, Mary. The Erosion of the Law of Controlling Shareholders. Delaware Journal of Corporate Law, v. 24, n. 1, 1999, pp. 27-81.

SMITH, Adam. A Riqueza das Nações: Investigação Sobre sua Natureza e suas Causas. Vol II. Trad.: Luiz João Baraúna. São Paulo: Nova Cultural, 1996, 879p. 